\title{
Towards balancing the oceanic Ni budget
}

S.H. Little ${ }^{1,2}$, C. Archer ${ }^{3}$, J. McManus ${ }^{4}$, J. Najorka ${ }^{5}$, A. V. Wegorzewski ${ }^{6}$, D. Vance ${ }^{3}$

1. Department of Earth Sciences, University College London, Gower Place, London WC1E 6BS, UK.

2. Department of Earth Science and Engineering, Royal School of Mines, Imperial College London, London, SW7 2BP, UK.

3. Institute of Geochemistry and Petrology, Department of Earth Sciences, ETH Zürich, Clausiusstrasse 25, 8092 Zürich, Switzerland.

4. Bigelow Laboratory for Ocean Sciences, 60 Bigelow Drive, P.O. Box 380, East Boothbay, Maine 04544, USA.

5. Core Research Laboratories, The Natural History Museum, Cromwell Road, London SW7 5BD, UK.

6. Federal Institute for Geosciences and Natural Resources (BGR), Stilleweg 2, D30655 Hannover, Germany.

Corresponding author: susan.little@ucl.ac.uk

For resubmission to: EPSL

3 June 2020 
3 Nickel isotopes are a novel and promising tracer of the chemistry of past ocean

4 environments, but realisation of this tracer's potential requires a comprehensive

5 understanding of the controls on Ni burial in the marine sedimentary archive. An

6 outstanding puzzle in the marine budget of $\mathrm{Ni}$, first recognised in the 1970s, is a major

7 imbalance in the known inputs and outputs to and from the ocean: the sedimentary

8 outputs of $\mathrm{Ni}$ are much larger than the inputs (rivers, dust). Much more recently, it has

9 also been recognised that the outputs are also considerably isotopically heavier than

10 the inputs. In this study, we find light $\mathrm{Ni}$ isotope compositions $\left(\delta^{60} \mathrm{Ni}_{\mathrm{NIST} \text { SRM986 }}=-0.2\right.$

11 to $-0.8 \%$ ) for Mn-rich sediments from the eastern Pacific compared to Fe-Mn crusts

12 (at about $+1.6 \%$ ). These data suggest that diagenetic remobilisation of isotopically

13 heavy Ni leads to a significant benthic Ni flux (estimated at $0.6-2.3 \times 10^{8} \mathrm{~mol} / \mathrm{yr}$ ),

14 similar in magnitude to the riverine flux, to the ocean. Diagenetic remobilisation of $\mathrm{Ni}$

15 may occur either via cycles of Mn-oxide dissolution and precipitation, with associated

16 Ni sorption and release, or during mineralogical transformation of birnessite to

17 todorokite. A minor role for retention of isotopically light Ni by Fe oxides or Fe-rich

18 authigenic clays is also proposed. Overall, a benthic flux of isotopically heavy Ni (at

19 about $+3 \%$ ) can balance the marine $\mathrm{Ni}$ budget, pinpointing diagenesis as a key

20 missing piece of the Ni puzzle. 


\section{Introduction}

26 Nickel is a cofactor in several enzyme systems central to the production of gases $\left(\mathrm{CO}_{2}\right.$,

$27 \mathrm{CO}$, methane, ammonia, $\mathrm{O}_{2}, \mathrm{H}_{2}$ ) that are important to the carbon, nitrogen and oxygen

28 cycles (reviewed by Ragsdale, 2009). Nickel is utilised by marine phytoplankton as

29 the metal centre in urease, which catalyses the breakdown of urea to $\mathrm{NH}_{3}$ and $\mathrm{CO}_{2}$

30 (e.g., Price and Morel, 1991). A Ni-containing superoxide dismutase (Ni-SOD)

31 enzyme is also present in some marine plankton groups, used to detoxify reactive

32 oxygen species (e.g., Palenik et al., 2003). All methanogens have an obligate Ni

33 requirement due to the presence of several Ni containing enzymes, including methyl-

34 coenzyme M reductase (e.g., Jaun and Thauer, 2007). Methane may have played a key

35 role in maintaining a warm climate on the early Earth, leading to interest in the

36 development of $\mathrm{Ni}$ and its isotopes as a biomarker for methanogenesis (e.g., Cameron

37 et al., 2009; Wang et al., 2019).

38

39 The stable isotopes of $\mathrm{Ni}$ (reported as $\delta^{60 / 58} \mathrm{Ni}=\left({ }^{60} \mathrm{Ni} /{ }^{58} \mathrm{Ni}_{\text {sample }} /{ }^{60} \mathrm{Ni} /{ }^{58} \mathrm{Ni}_{\text {SRM986 }}-1\right) \times$ 40 1000) could help to quantify and understand these issues in the past. However, the 41 development of a new isotope system as a tracer requires characterization of its 42 modern biogeochemical cycling. Indeed, stable isotope ratios provide useful 43 constraints on elemental global mass balances; that is, the input and output fluxes of 44 an element to and from the ocean. If we assume steady state, the Ni input and output 45 fluxes should balance (equation 1), as should their flux-weighted isotopic 46 compositions (equation 2):

47

$$
\text { (1) } F_{\text {input }}=F_{\text {output }}
$$


where $F_{\text {input }}$ and $F_{\text {output }}$ are the respective input and output flux magnitudes, and $\delta_{\text {input }}$

51 and $\delta_{\text {output }}$ their isotopic compositions. For our discussion here we assume that Ni is at steady state over the past $10-20 \mathrm{kyr}$, i.e., on the timescale of the oceanic residence time of $\mathrm{Ni}$ (Ciscato et al., 2018 this study).

Current best estimates of the inputs and outputs of $\mathrm{Ni}$ to and from the oceanic dissolved pool are not in balance (Krishnaswami, 1976; Gall et al., 2013; Cameron and Vance, 2014; Gueguen et al., 2016; Ciscato et al., 2018; Spivak-Birndorf et al., 2018). The estimated total input of $\mathrm{Ni}$ to the ocean is approximately half of the total sedimentary output fluxes. In addition, the known inputs are isotopically light (at about $+0.8 \%$; Cameron and Vance, 2014) compared to seawater (at about $+1.4 \%$; Archer et al., 2020; Cameron and Vance, 2014; Takano et al., 2017; Wang et al., 2018), while most of the sedimentary outputs are isotopically similar to or heavier than seawater (Gall et al., 2013; Gueguen et al., 2016; Ciscato et al., 2018). Balancing the steady-state Ni budget either requires an isotopically heavy Ni input or an isotopically light output flux, or both of these.

One key oceanic output flux of $\mathrm{Ni}$ is sorption to dispersed Fe-Mn oxide phases found throughout oxygenated deep sea sediments, for which the isotopic composition of FeMn crusts has been used as a proxy (Cameron and Vance, 2014; Ciscato et al., 2018). The Ni isotope composition of Fe-Mn crusts is variable, but generally similar to or heavier than seawater, with average $\delta^{60} \mathrm{Ni}_{\mathrm{Fe}-\mathrm{Mn} \text { crust }}=+1.62 \pm 0.37 \%$ o $(\mathrm{n}=28 ; 1 \mathrm{SD}$, Gall et al., 2013; Gueguen et al., 2016). Nickel is sorbed to the Mn oxide phase in Fe- 
73 Mn crusts: specifically, to a poorly crystalline phyllomanganate of the birnessite 74 family (termed vernadite/ $\delta-\mathrm{MnO}_{2}$ ) (e.g., Koschinsky and Halbach, 1995; Koschinsky 75 and Hein, 2003; Peacock and Sherman, 2007a). However, sediments and Mn nodules 76 contain a mixture of vernadite and more crystalline $7 \AA$ and $10 \AA$ birnessite phases, 77 which transform to the tectomanganate phase todorokite during diagenesis (e.g., Burns 78 and Burns, 1979; Atkins et al., 2014). Recent experiments and the study of todorokiterich buried Mn nodules have shown that $\sim 50 \%$ of sorbed $\mathrm{Ni}$ is released to the aqueous phase during this mineralogical transformation (Atkins et al., 2016; Heller et al., 2018). In addition, remobilization of $\mathrm{Ni}$ is observed in the Mn oxide reduction zone in sub-oxic sediment porewaters (e.g., Klinkhammer, 1980; Heggie et al., 1986), where 'sub-oxic' denotes low concentrations of both oxygen and sulphide. Either transformation to todorokite or the reduction of Mn oxides may lead to a decreased $\mathrm{Ni}$ trapping efficiency in sediments and a benthic return flux of Ni to seawater.

As yet, the potential for isotope fractionation during diagenetic Ni remobilization has not been evaluated. We show that diagenesis significantly modifies the output flux of $\mathrm{Ni}$ from the oceans, and infer a benthic return flux of isotopically heavy $\mathrm{Ni}$. We explore the extent to which this benthic flux can balance the oceanic Ni budget.

\section{Sites and Samples}

93

94 Metalliferous sediment samples were selected from two of the five MANOP 95 (Manganese nodule project) sites, $\mathrm{M}$ and $\mathrm{H}$, both in the Guatemala Basin (Fig. 1). 96 Both sites are oxygenated at the sediment-water interface and sub-oxic below 97 (Klinkhammer, 1980). A surface nitrate maximum overlies a zone of Mn cycling, with 
103

104

105

106

107

108

109

detectable porewater $\mathrm{Mn}$ at depths $>6 \mathrm{~cm}$ at Site $\mathrm{M}$, and $>12 \mathrm{~cm}$ at Site H. Porewater Fe is observed at depths $>13 \mathrm{~cm}$ at site $\mathrm{M}$ only (Fig. 3; Klinkhammer, 1980; Heggie et al., 1986). Samples were collected using a $50 \mathrm{~cm}$ x $50 \mathrm{~cm}$ box corer and later subsampled with a plastic core liner, using a piston to avoid core shortening. Five-six subsamples from the upper $20 \mathrm{~cm}$ of each core were included in this study.

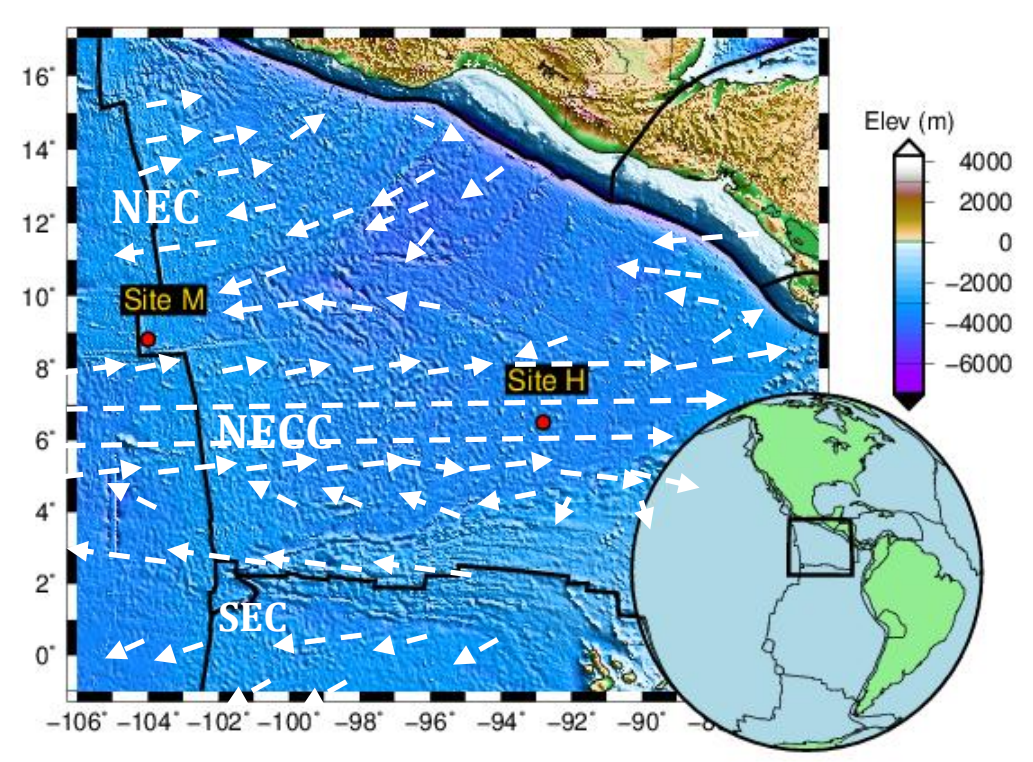

Figure 1. Map of the Guatemala Basin showing the two MANOP site locations. Site $\mathrm{M}$ is close to the East Pacific Rise, Site $\mathrm{H}$ is located on the flat plain of the Guatemala Basin. Tectonic plate boundaries in black; surface ocean currents as white arrows (NECC, North Equatorial Counter Current; NEC, North Equatorial Current; SEC, South Equatorial Current) from Kessler (2006). Insert shows the location of the grid.

MANOP site M, chosen by MANOP to represent hydrothermal sedimentation, is located $25 \mathrm{~km}$ east of the spreading axis of the East Pacific Rise, at $8.8^{\circ} \mathrm{N} 104.0^{\circ} \mathrm{W}$, $\sim 3.1 \mathrm{~km}$ water depth (Fig. 1). The site is just 1,000 km away from the Central American coast and within the source region of the westward flowing North Equatorial Current (NEC). As a result, site $M$ has a sedimentation rate of about 1 cm/1000 year (Kadko, 1981), with a combination of continental, hydrothermallyderived, and biogenic sediment (at $\sim 130 \mu \mathrm{g} \mathrm{C}_{\mathrm{org}} / \mathrm{cm}^{2} \mathrm{yr}$; Lyle et al., 1984). Surface 
117 sediments at site $\mathrm{M}$ contain $10-40 \%$ calcium carbonate, $5-9 \%$ opal, and $1-2 \%$ organic

118 carbon (Lyle et al., 1984).

120 MANOP site $\mathrm{H}$, the hemipelagic MANOP site, is located approximately $1,000 \mathrm{~km}$ east

121 of the East Pacific Rise on a relatively flat plain in the Guatemala Basin, at $6.5^{\circ} \mathrm{N}$

$12292.8^{\circ} \mathrm{W}, \sim 3.6 \mathrm{~km}$ water depth. It lies at the northern edge of the eastward flowing

123 North Equatorial Counter-Current (NECC) and at the southwestern edge of the

124 productive Costa Rica Dome. The organic C flux at this site is similar to that at site M,

125 at $\sim 110 \mu \mathrm{g} \mathrm{C}$ org $/ \mathrm{cm}^{2}$ yr (Lyle et al., 1984). The site is currently at or just below the

126 calcite compensation depth, and the sedimentation rate, at $\sim 0.65 \mathrm{~cm} / 1000 \mathrm{yr}$, is about

127 half of that of site $\mathrm{M}$ due to greater dissolution of biogenic debris (carbonate) and the

128 lower quantity of continent-derived material (Kadko, 1981; Lyle et al., 1984).

130 Bulk samples of six well-characterized Mn nodule samples were also analysed for

131 their Ni isotope compositions in this study (Table 1). These include the two USGS

132 reference materials Nod P1 and Nod A1, one surface and two buried Fe-Mn nodules

133 from the Clarion-Clipperton Zone (CCZ) of the equatorial North Pacific (sites 21KG,

134 22KL; full details in: Heller et al., 2018; Wegorzewski et al., 2020) and one shallow

135 buried nodule from the Peru Basin (site 77BC). The selected surface and buried

136 nodules have evolved under differing redox regimes and are therefore compositionally

137 diverse, allowing comparisons to be made between phyllomanganate-rich and

138 todorokite-rich nodules (Table 1; Wegorzewski et al., 2020).

140 Table 1. Mn nodule samples studied, with predominant mineralogy as determined by 141 XRD analysis (Wegorzewski et al., 2020)

\begin{tabular}{llll}
\hline Mn Nodule Location & $\begin{array}{l}\text { Water depth/ } \\
\text { Depth in sediment }\end{array}$ & Mineralogy \\
\hline
\end{tabular}




\begin{tabular}{|c|c|c|c|}
\hline Nod A1 & $\begin{array}{l}\text { Atlantic } \\
31^{\circ} 02^{\prime} \mathrm{N} \\
78^{\circ} 22^{\prime} \mathrm{W}\end{array}$ & $\begin{array}{l}788 \mathrm{~m} / \\
\text { Surface }\end{array}$ & Phyllomanganates \\
\hline Nod P1 & $\begin{array}{l}\text { Pacific } \\
14^{\circ} 50^{\prime} \mathrm{N} \\
124^{\circ} 28^{\prime} \mathrm{W}\end{array}$ & $\begin{array}{l}4300 \mathrm{~m} / \\
\text { Surface }\end{array}$ & Phyllomanganates \\
\hline 21KG-1n & $\begin{array}{l}\text { CCZ, Pacific } \\
13^{\circ} 10.529^{\prime} \mathrm{N} \\
118^{\circ} 08.187^{\prime} \mathrm{W}\end{array}$ & $\begin{array}{l}4288 \mathrm{~m} / \\
\text { Surface }\end{array}$ & $\begin{array}{l}\text { Diagenetic growth structures: } 7 \text { and } \\
10 \AA \text { phyllomanganates and } \\
\text { hydrogenetic growth structures: } \\
\text { vernadite }\left(\delta-\mathrm{MnO}_{2}\right) \text { that is epitaxially } \\
\text { intergrown with an amorphous } \\
\text { FeOOH phase }\end{array}$ \\
\hline 77BC11-6 & $\begin{array}{l}\text { Peru Basin, } \\
\text { Pacific } \\
7^{\circ} 04.575^{\prime} \mathrm{S} \\
88^{\circ} 31.577^{\prime} \mathrm{W}\end{array}$ & $\begin{array}{l}4130.5 \mathrm{~m} / \\
\text { Shallowly buried }\end{array}$ & Mainly Todorokite \\
\hline $22 \mathrm{KL}-530 \mathrm{~cm}$ & $\begin{array}{l}\text { CCZ, Pacific } \\
13^{\circ} 10.527^{\prime} \mathrm{N} \\
118^{\circ} 08.184^{\prime} \mathrm{W}\end{array}$ & $\begin{array}{l}4302 \mathrm{~m} / \\
\text { Deeply buried } 530 \mathrm{~cm}\end{array}$ & $\begin{array}{l}\text { Mainly Todorokite, minor } \\
\text { phyllomanganates }\end{array}$ \\
\hline $22 \mathrm{KL}-801 \mathrm{~cm}$ & $\begin{array}{l}\text { CCZ, Pacific } \\
13^{\circ} 10.527^{\prime} \mathrm{N} \\
118^{\circ} 08.184^{\prime} \mathrm{W}\end{array}$ & $\begin{array}{l}4302 \mathrm{~m} / \\
\text { Deeply buried } 801 \mathrm{~cm}\end{array}$ & $\begin{array}{l}\text { Mainly Todorokite, minor } \\
\text { phyllomanganates }\end{array}$ \\
\hline
\end{tabular}

142

\section{3. Analytical Methods}

\subsection{MANOP mineralogy by XRD}

146 Selected samples from MANOP sites $\mathrm{H}$ and $\mathrm{M}$ (Table 2) were analysed by X-ray 147 diffractometry for their bulk mineralogy using a PANalytical X'Pert PRO instrument 148 at the Natural History Museum, London. Phase quantification was subsequently 149 attempted via a Rietveld refinement analysis of the $10-90^{\circ} 2 \theta$ region. Note that the 150 detection limit for the XRD analyses corresponds to about $1-5 \mathrm{wt} \%$, depending on 151 the crystallinity and crystal symmetry of the phase (where a higher crystallinity and 152 crystal symmetry of a phase corresponds to a lower detection limit). For full details of 153 the XRD analyses, see the Supplementary Information.

\section{$155 \quad 3.2$ Element concentrations and $\mathrm{Ni}$ isotope ratios}


156 Bulk sample digestion was carried out in clean laboratories at ETH Zürich or Imperial

157 College London, following previously published methods (Cameron and Vance, 2014;

158 Vance et al., 2016; Ciscato et al., 2018; Archer et al., 2020). Between 20 and $100 \mathrm{mg}$

159 of each sample was pre-digested by treatment with concentrated $\mathrm{HNO}_{3}$ to attack

160 carbonates, then completely digested in a 3:1 mixture of concentrated $\mathrm{HF}$ and $\mathrm{HNO}_{3}$ -

161 on a hotplate for 48 hours. Residual fluorides were removed by triplicate treatment

162 with concentrated $\mathrm{HNO}_{3}$, before final dissolution in $6 \mathrm{~mL} \mathrm{7M} \mathrm{HCl}$. Aliquots of these

163 digest solutions were taken for multi-element analysis on a Thermo Element XR at

164 ETH Zürich. Sub-samples were then spiked with a ${ }^{61} \mathrm{Ni}-{ }^{62} \mathrm{Ni}$ double spike to achieve a

165 sample-spike ratio of approximately 1 prior to column chromatography. Two different

166 column chromatography procedures were utilised in this study, detailed in Figure 2

167 and modified following Cameron and Vance (2014), Ciscato et al. (2018) and Archer

168 et al. (2020). For full details, see the Supplementary Information.

169

170

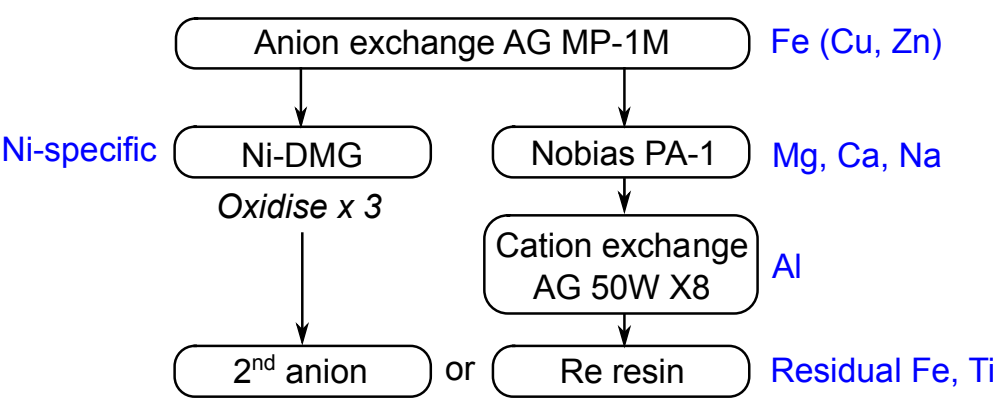

171 Figure 2. Flowchart illustrating the two alternative Ni column chromatography procedures utilised in this study. Full details given in the Supplementary Information.

174 Nickel isotope compositions were analysed on a Neptune Plus multi-collector ICP-MS

175 at ETH Zürich (Vance et al., 2016; Ciscato et al., 2018) and are reported relative to the

176 NIST SRM986 Ni standard, as: 
(2) $\quad \delta^{60 / 58} \mathrm{Ni}=\left(\frac{\left({ }^{60} \mathrm{Ni} /{ }^{58} \mathrm{Ni}\right)_{\text {sample }}}{\left({ }^{60} \mathrm{Ni} /{ }^{58} \mathrm{Ni}\right)_{\text {SRM }} 986}-1\right) \times 1000$

179

180 Accuracy and precision of the $\mathrm{Ni}$ isotope ratio measurements were monitored by 181 repeated analysis of the primary NIST solution standard at a range of sample:spike 182 ratios ( 0.2 to 5$)$, and the repeated digestion and analysis of two reference materials, 183 USGS standards Nod P1 $(+0.34 \pm 0.05 \%$, $2 \mathrm{SD}, \mathrm{n}=5)$ and Nod A1 $(+1.06 \pm 0.02 \%$, $1842 \mathrm{SD}, \mathrm{n}=5)$. The long-term reproducibility $( \pm 0.07 \%)$ was assessed by repeat 185 measurements of primary standards and one of the secondary standards, Nod A1 186 (digested and passed through the Ni column chemistry), the latter giving $\delta^{60} \mathrm{Ni}=+1.04$ $187 \pm 0.07 \%$ o ( $2 \mathrm{SD}, \mathrm{n}=175$ over 4 years $)$, in agreement with previously published results 188 (Gueguen et al., 2016).

189

\section{Results}

\subsection{Mineralogy and geochemistry}

193 The bulk mineral assemblages of the four MANOP samples analysed by XRD are 194 similar (Table S1, Figs S1-S4). The major mineral phase in all samples is smectite (49 $195-60 \mathrm{wt} \%)$. Other minerals present in all samples include calcite $(0.1-22 \mathrm{wt} \%)$, 196 plagioclase $(13-20 \mathrm{wt} \%)$, quartz $(4-6 \mathrm{wt} \%)$, halite $(4-5 \mathrm{wt} \%)$, kaolinite $(4-6$ $197 \mathrm{wt} \%)$ and barite $(1-3 \mathrm{wt} \%)$. A Mn oxide phase, tentatively identified as birnessite, is 198 present at levels close to the detection limit of the XRD analysis $(0.3-2 \mathrm{wt} \%)$. 199 Muscovite (4 wt\%) is identified in the sample from site M (8967, 1-3 cm depth) only, 200 representing the only notable difference between this sample and the deepest sample at 201 site $H(5313,19-21 \mathrm{~cm})$, which are otherwise similar in their phase quantification 202 (Table S1). 
204 Elemental concentrations of the MANOP samples (Table 2, Table S2) are consistent 205 with the mineralogical information. Aluminium and Ti, expected to be present largely 206 in the silicate (i.e. clay mineral) fraction, are somewhat higher at site $\mathrm{H}(\sim 5$ and $\sim 0.3$ $207 \mathrm{wt} \%$, respectively) than site $\mathrm{M}(\sim 4.2$ and $\sim 0.2 \mathrm{wt} \%)$, reflected in a higher proportion of 208 smectite at site H (Table S1). However, Fe concentrations are elevated at site M ( 5.5 $209 \mathrm{wt} \%)$ compared to site $\mathrm{H}(\sim 4 \mathrm{wt} \%)$, and $\mathrm{Fe} / \mathrm{Al}$ ratios at site $\mathrm{M}$ are significantly higher 210 than lithogenic values (e.g., upper continental crust, UCC; Fig. 3). Manganese 211 concentrations are high, particularly in the upper $10 \mathrm{~cm}$ at site $\mathrm{H}$ (at $\sim 5 \mathrm{wt} \%$ ), 212 dropping to $\sim 2 \mathrm{wt} \%$ below this. The deepest sample at site $\mathrm{M}$ has a considerably lower 213 Mn content than the other samples, at $0.1 \mathrm{wt} \%$.

215 Trace metal concentrations (e.g., $\mathrm{Ni}, \mathrm{Cu}, \mathrm{Zn}, \mathrm{Mo}, \mathrm{Cd}$ ), are significantly enriched at 216 both sites $\mathrm{H}$ and $\mathrm{M}$ relative to expected detrital abundances, e.g., as found in UCC 217 (Table 2, Table S2, Fig. 3), with enrichments typically greater at site $\mathrm{H}$ than at site $\mathrm{M}$. 218 There is a coupling between $\mathrm{Mn}$ enrichment and those of $\mathrm{Ni}, \mathrm{Cu}$ and $\mathrm{Zn}$, particularly 219 clear at Site H, where the three shallowest samples $(<10 \mathrm{~cm}$ depth) are considerably 220 more enriched than the three deeper samples (at $10-20 \mathrm{~cm}$ ) (Fig. 3).

222 Manganese contents of Nod P1 and the CCZ surface and buried nodules are similar 223 (Table 2), at 31 to $32 \mathrm{wt} \%$, while Fe contents are somewhat lower in buried nodules 224 (at $\sim 3 \mathrm{wt} \%$ ) than surface nodules (at $4-5 \mathrm{wt} \%$ ). The Peru Basin nodule has an even 225 higher $\mathrm{Mn}$ content (at $\sim 48 \mathrm{wt} \%$ ). Nickel concentrations are highest in the Pacific 226 surface nodules (at $\sim 1.1 \mathrm{wt} \%$ ) and lower in the deeply buried nodules (at $\sim 0.7-0.8$ $227 \mathrm{wt} \%)$. As a result, $\mathrm{Ni} / \mathrm{Mn}$ ratios are lower in buried $(\sim 0.025)$ than surface $(\sim 0.038)$ 
nodules. For a full discussion of the elemental distribution patterns in the CCZ nodules, see Heller et al. (2018). Atlantic Nod A1, which was collected from a much

230 shallower water depth (776 m; Table 1) than the Pacific nodules, has a lower Mn 231 content $(20 \mathrm{wt} \%)$, a higher $\mathrm{Fe}$ content $(10 \mathrm{wt} \%)$ and lower trace element 232 concentrations (e.g., $0.6 \mathrm{wt} \% \mathrm{Ni}, 0.1 \mathrm{wt} \% \mathrm{Cu}$ ), and an intermediate $\mathrm{Ni} / \mathrm{Mn}$ ratio 233 (0.029).
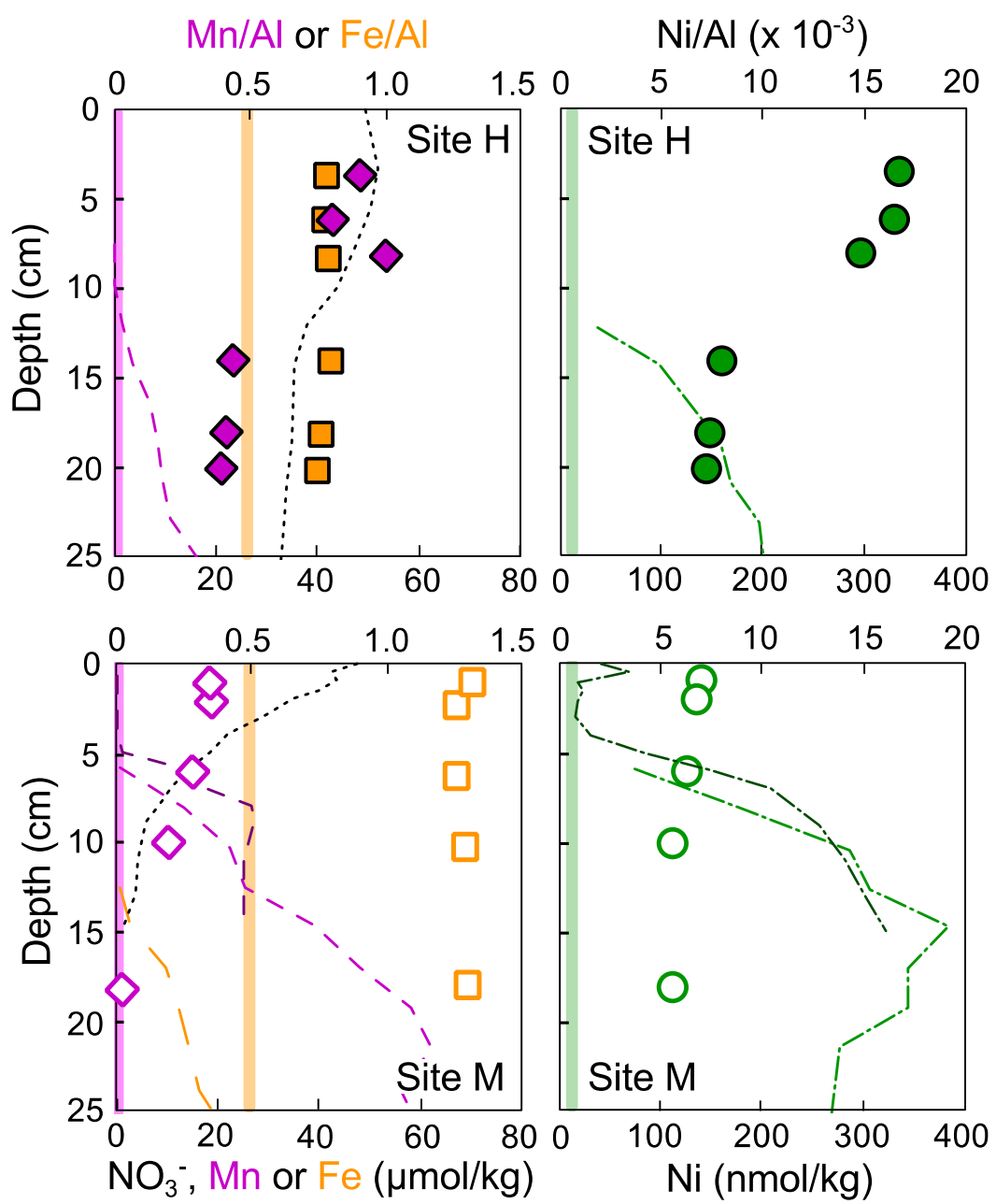

Figure 3. Solid-phase $\mathrm{Mn} / \mathrm{Al}$ (purple diamonds), Fe/Al (orange squares), and Ni/Al (green circles) ratios in the sediment at the two MANOP sites. Filled symbols - site H, open symbols - site M. Solid coloured bars illustrate upper continental crust Me/Al ratios, from Rudnick and Gao (2003). Porewater concentrations of $\mathrm{NO}_{3}{ }^{-}$(black dotted lines), Mn (purple dashed lines), Fe (site M only, orange long dashed line) and $\mathrm{Ni}$ (green dot-dashed lines) from Klinkhammer (1980: Site H and M) and Heggie et al. 
(1986; Site M only: darker coloured lines for Mn, Ni) are overlain on secondary xaxes.

\subsection{Ni isotope compositions}

The Ni isotope compositions of samples from both MANOP sites are light relative to seawater, ranging from -0.79 to $-0.17 \%$ (Table 2 ; Fig. 4 ). $\delta^{60} \mathrm{Ni}$ values for site $\mathrm{H}$ are approximately homogeneous with depth, with mean $\delta^{60} \mathrm{Ni}_{\mathrm{H}}=-0.21 \pm 0.09 \%$ (2 SD). Site $\mathrm{M} \delta^{60} \mathrm{Ni}$ values are more negative than those of site $\mathrm{H}$, and become isotopically

252

lighter with depth, with $\delta^{60} \mathrm{Ni}_{\mathrm{M}}$ from -0.42 to $-0.79 \%$. MANOP $\delta^{60} \mathrm{Ni}$ values are much more negative than deep seawater, with $\delta^{60} \mathrm{Ni}_{\text {seawater }}=+1.34 \pm 0.07 \%$ ( $1 \mathrm{SD}$, seawater samples >200m; Cameron and Vance, 2014; Takano et al., 2017; Wang et al., 2018; Archer et al., 2020), and than Fe-Mn crusts, with $\delta^{60} \mathrm{Ni}_{\mathrm{FeMnCrust}}=+1.62 \pm 0.37 \%$ o $(1$ SD, Gall et al., 2013; Gueguen et al., 2016).

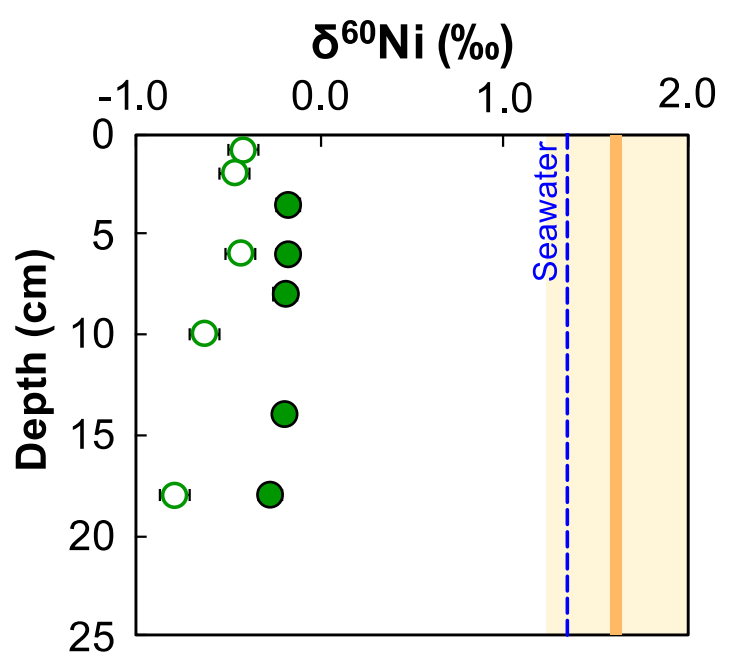

Figure 4. Ni isotope compositions for samples from MANOP site H (filled symbols) and site $\mathrm{M}$ (open symbols) with depth in the sediment. Error bars (similar to symbol size) are the long-term reproducibility of the secondary standard $( \pm 0.07 \%)$. Blue dashed line: deep seawater $\delta^{60} \mathrm{Ni}$ (Cameron and Vance, 2014; Takano et al., 2017; Wang et al., 2018; Archer et al., 2020). Orange solid bar and shaded region: Fe-Mn crust $\delta^{60} \mathrm{Ni}$, mean and 1SD (Gall et al., 2013; Gueguen et al., 2016). 
266 The Pacific Mn nodules from the ocean floor (Nod P1, 21KG-1n), which are

267 predominantly phyllomanganates, have $\delta^{60} \mathrm{Ni}$ values of +0.34 and $+0.28 \%$ (Table 2 )

268 The two deeply buried nodules (22KL $530 \mathrm{~cm}$ and $801 \mathrm{~cm}$ ), comprised mostly of 269 todorokite, have lower $\delta^{60} \mathrm{Ni}$ values, at $-0.08 \%$ and $+0.01 \%$. The Peru Basin nodule 270 (77BC11-6) is also predominantly todorokite and is isotopically the lightest of the six 271 nodules, at $-0.22 \%$. Nod A1 from the Atlantic has a heavier Ni isotope composition, 272 at $\delta^{60} \mathrm{Ni}=+1.06 \%$ (Table 2$)$.

\section{Discussion}

The sediment samples from the two MANOP sites have the lightest $\mathrm{Ni}$ isotope composition yet measured for modern marine sediments (at -0.2 to $-0.8 \%$ ), considerably lighter than Fe-Mn crusts (about $+1.6 \%$; Gall et al., 2013; Gueguen et al., 2016), organic-rich sediments (about $+1.1 \%$; Ciscato et al., 2018), euxinic 280 sediments from the Black Sea (about $+0.2 \%$; Vance et al., 2016), and the lithogenic Ni 281 isotope composition (about $+0.1 \%$; Cameron et al., 2009). All MANOP samples are 282 also at least 20-fold enriched in Ni compared to the UCC (Fig. 3; Table 2); hence, the 283 lithogenic $\mathrm{Ni}$ component in these sediments is minor. We consider two possible 284 origins for isotopically light authigenic $\mathrm{Ni}$ : (1) an isotopically light source of $\mathrm{Ni}$ or (2) 285 isotope fractionation during diagenesis.

\subsection{An isotopically light source of Ni to the MANOP sites?}

289 One possible source of $\mathrm{Ni}$ to sediments is from the dissolved pool in seawater; a 290 diffusive flux of $\mathrm{Ni}$ was recently suggested to contribute to $\mathrm{Ni}$ accumulation in 
291 oxygen-deficient continental margin sediments (Ciscato et al., 2018). However, a 292 diffusive flux requires higher $\mathrm{Ni}$ concentrations in bottom waters compared to 293 porewaters. Dissolved Ni concentrations measured in core-top porewaters at the 294 MANOP sites are similar to or, at site M, higher than bottom waters (Fig. 3; 295 Klinkhammer, 1980; Heggie et al., 1986), suggesting, if anything, a small benthic flux 296 of $\mathrm{Ni}$ out of porewaters. Alternatively, Ni in seawater may be scavenged by particulate 297 material in the water column, providing a 'hydrogenetic' source of Ni to sediments. 298 Models of hydrogenetic Fe-Mn crust formation have emphasized the importance of 299 inorganic sorption processes of this type (e.g., Koschinsky and Hein, 2003). If Fe-Mn 300 crusts represent the hydrogenetic Ni source to sediments, Ni that is isotopically similar 301 to or heavier than seawater, at $+1.62 \pm 0.37 \%$ (1 SD, Gall et al., 2013; Gueguen et al., 302 2016) would be expected in the MANOP sediments.

304 Nickel displays a typical nutrient-type profile in seawater (e.g., Bruland, 1980). 305 Furthermore, a strong correlation with organic carbon is observed in sediments 306 underlying upwelling zones, suggesting organic matter is an important supply route of 307 Ni to sediments (e.g., Fig S7; Ciscato et al., 2018). Cellular Ni/P ratios from the mixed 308 layer of the equatorial Pacific range from $0.25-1.15 \mathrm{mmol} / \mathrm{mol}$ (measured by 309 synchrotron XRF; Twining et al., 2012), similar to ratios for plankton tows from 310 nearby MANOP sites (0.51 to $0.96 \mathrm{mmol} / \mathrm{mol}$; Collier and Edmond, 1984). Both 311 MANOP sites receive high fluxes of biogenic particulate material, with $\mathrm{C}_{\text {org }}$ rain rates 312 of $110-130 \mu \mathrm{g} \mathrm{C}_{\mathrm{org}} / \mathrm{cm}^{2} / \mathrm{yr}$ (Lyle et al., 1984). Given these values, we calculate that 313 approximately $5-10 \%$ of the $\mathrm{Ni}$ budget in the MANOP sediments is supplied by 314 organic matter (see Table S3 for details). However, higher particulate $\mathrm{Ni} / \mathrm{P}$ ratios of 315 about $5-15 \mathrm{mmol} / \mathrm{mol}$ are observed below the mixed layer in the eastern Pacific (Fig. 
316 S5; Ohnemus et al., 2017), suggesting that preferential $\mathrm{P}$ remineralisation occurs as 317 organic-rich particles settle through the water column (recently suggested in the 318 context of $\mathrm{Cd} / \mathrm{P}$; Bourne et al., 2018). The links between export production and 319 sedimentary metal concentrations is an area of active research, but we note that a 320 particulate $\mathrm{Ni} / \mathrm{P}$ ratio of $\sim 15 \mathrm{mmol} / \mathrm{mol}$ could account for $\sim 100 \%$ of the $\mathrm{Ni}$ in the 321 MANOP sediments (Table S3).

323 Organic matter is therefore a significant source of Ni to the MANOP sediments, but is 324 it isotopically light? The limited dataset for upper water column $\delta^{60} \mathrm{Ni}$ (Takano et al., 325 2017; Wang et al., 2018; Archer et al., 2020) suggest that phytoplankton do 326 preferentially take up isotopically light Ni. However, the maximum fractionation 327 factor implied by water column data for biological uptake is rather small, at about $3280.3 \%$ (Archer et al., 2020). Consistent with this inference, Takano et al. (2020) 329 estimate the $\delta^{60} \mathrm{Ni}$ of biogenic particles in the South China Sea to be +0.6 to $+1 \%$. 330 Hence, Ni in organic matter exported from the photic zone is not expected to be nearly 331 light enough to explain the MANOP $\delta^{60} \mathrm{Ni}$ values (at -0.2 to $-0.8 \%$ ). Furthermore, 332 modern organic-rich sediments from the Peru margin have bulk $\mathrm{Ni}$ isotope 333 compositions of $+1.12 \pm 0.08 \%$ ( $1 \mathrm{SD}, \mathrm{n}=25$; Ciscato et al., 2018), consistent with the 334 water column data and suggesting that particle cycling on transit from the photic zone 335 to sediment is not associated with significant isotopic fractionation. Organic matter 336 cannot explain the light $\mathrm{Ni}$ isotope compositions observed at the MANOP sites.

338 A third possible source of $\mathrm{Ni}$, particularly site $\mathrm{M}$, which is $25 \mathrm{~km}$ east of the East 339 Pacific Rise, is hydrothermal sedimentation. To our knowledge, $\delta^{60} \mathrm{Ni}$ values have not 340 been measured in hydrothermal fluids, but may be expected to be isotopically light, 
341 similar to lithogenic $\mathrm{Ni}$, at about $+0.1 \%$ (Cameron et al., 2009). However, a direct Ni

342 source from hydrothermal fluids is unlikely; recent GEOTRACES sections suggest

343 that hydrothermal plumes may instead be sites of Ni removal from seawater via

344 scavenging (discussed by Ciscato et al., 2018). Using an endmember mixing model,

345 Fischer (1983) estimates that $\sim 10 \%$ of the $\mathrm{Ni}$ (but $\sim 50 \%$ of the $\mathrm{Fe}$ ) at site $\mathrm{M}$

346 (compared to $<1 \%$ of the $\mathrm{Ni}$ at site $\mathrm{H}$ ) is hydrothermally sourced. We consider a 347 possible role for hydrothermally sourced $\mathrm{Fe}$ to sedimentary Ni cycling at site $\mathrm{M}$ in 348 section 5.3.

\subsection{Nickel isotope fractionation during diagenesis: coupling of Ni-Mn}

352 Having ruled out an isotopically light source of Ni to the sediment, we suggest that 353 post-depositional processes are responsible for the MANOP Ni isotope compositions. 354 First, we consider two processes coupled to Mn diagenesis: (1) cycles of Mn oxide 355 dissolution and reprecipitation ('Mn cycling') and (2) transformation of birnessite to 356 todorokite ('todorokite transformation').

\section{Manganese cycling}

359 Porewater data from the MANOP sites (Klinkhammer, 1980; Heggie et al., 1986)

360 illustrate the clear coupling between $\mathrm{Mn}$ and Ni cycling - via cycles of Mn-oxide 361 dissolution and precipitation (Fig. 3). Sorbed Ni is released to porewaters upon $\mathrm{Mn}$ 362 oxide dissolution, and resorbed on newly precipitating Mn oxide phases within the 363 shallower oxygenated zone. Manganese oxides are strong sorbents for divalent trace 364 metals like $\mathrm{Ni}$ due to their negative surface layer charge at the $\mathrm{pH}$ of natural waters 365 (e.g., Burns and Burns, 1979; Koschinsky and Halbach, 1995). In particular, 
phyllomanganates like birnessite, which has a layered structure of edge-sharing $\mathrm{MnO}_{6}$

367 octahedra, are ubiquitous in the natural environment and are the main Mn-bearing and

368 trace metal-sorbing phases in oxic marine sediments (e.g., Peacock and Sherman,

369 2007a; Little et al., 2014). Experimental estimates of the magnitude of $\mathrm{Ni}$ isotope

370 fractionation on sorption to birnessite suggest a large light isotope effect, with a recent

371 study reporting $\Delta^{60} \mathrm{Ni}_{\mathrm{MnO2} \text {-aqueous }}=-2.8$ to $-3.4 \%$ (Sorensen et al., 2020).

373 The pattern of variation in Ni concentration and isotopic composition across the Black

374 Sea redoxcline (Vance et al., 2016) is qualitatively and quantitatively consistent with

375 these experimental data, with sorption to particulate Mn oxides above the redoxcline

376 preferring the light $\mathrm{Ni}$ isotopes by about $4 \%$. We hypothesize that a similar process

377 takes place in sediment porewaters, explaining (at least in part) the light isotopic

378 compositions of the MANOP sediments. The smaller $\Delta^{60} \mathrm{Ni}_{\text {MANOP-seawater }}$ offset of

379 about -1.6 to $-2.4 \%$ compared to experiments and the Black Sea likely reflects the

380 fact that the porewater-sediment system is not completely open.

382 In the context of the experimental data, the observations in the Black Sea, and the new 383 data here, the published data for hydrogenetic Fe-Mn crusts stand out as different. 384 Most Fe-Mn crusts analysed to date are isotopically similar to or heavier than seawater 385 (Fig. 5A). Sorensen et al. (2020) suggest three possible explanations for this 386 observation. The first involves differences in the mechanism of incorporation into the 387 solid structure. Nickel in slow-growing Fe-Mn crusts is predominantly structurally 388 incorporated into birnessite (specifically vernadite $\left./ \delta-\mathrm{MnO}_{2}\right)$ vacancy sites $($ Peacock 389 and Sherman, 2007a), while adsorption in experiments occurs primarily as a triple390 corner-sharing surface complex over the vacancy sites (Peacock and Sherman, 2007b; 
391 Sorensen et al., 2020). Surface complexation is also likely to be dominant in dynamic 392 open system environments like the redoxcline of the Black Sea. It is possible, 393 therefore, that structural incorporation of $\mathrm{Ni}$ is associated with a different isotope 394 effect than adsorption as a surface complex. A second explanation relates to reaction 395 kinetics, with slow-growing (a few $\mathrm{mm} / \mathrm{Ma}$ ) Fe-Mn crusts exhibiting long-term 396 isotopic equilibration of $\mathrm{Ni}$ with seawater; exchangeability of $\mathrm{Ni}$ in Fe-Mn crusts has 397 recently been demonstrated by Hens et al. (2019). Finally, it has been suggested that 398 Ni speciation in seawater may control the isotopic composition of the sorbing Ni 399 species, with a possible role for organic complexation (Sorensen et al., 2020).

401 Fe-Mn crusts are not only marked by relatively positive $\delta^{60} \mathrm{Ni}$ values, but also by 402 significant variability in $\delta^{60} \mathrm{Ni}$ (Fig. $5 \mathrm{~A},+0.41$ to $+2.47 \%$; Gall et al., 2013), which 403 may reflect the complexities of the aforementioned processes. We note, however, that 404 a depth profile through one crust (ZEP2-DR05-04) from the Pacific Ocean shows a 405 marked transition towards much lighter Ni isotope compositions coupled to decreasing $406 \mathrm{Mn} / \mathrm{Ni}$ ratios at depth (Fig. 5B; Gueguen et al., 2016). The authors attributed this 407 transition to lighter isotopic compositions to the reductive dissolution of primary $\mathrm{Mn}$ 408 oxide phases followed by their reprecipitation and the resorption of $\mathrm{Ni}$ in an open 409 system (Gueguen et al., 2016) - i.e. the same process of Mn cycling described here.

411 Phyllomanganate-rich surface Mn nodules may also record the impact of Mn cycling 412 in their Ni isotope compositions, because they contain Ni from both hydrogenetic and 413 diagenetic sources. They consist of hydrogenetic layers formed by precipitation from 414 seawater (vernadite $/ \delta-\mathrm{MnO}_{2}$ and amorphous $\mathrm{FeOOH}$ ) and diagenetic layers formed 415 during re-precipitation from sub-oxic porewaters (primarily 7 and $10 \AA$ birnessite) 
416 (e.g., Koschinsky and Halbach, 1995; Heller et al., 2018). These nodules are variably

417 isotopically light (at +0.28 to $+1.06 \%$ ) compared to seawater, and fall close to the

$418 \mathrm{Mn} / \mathrm{Ni} \vee \delta^{60} \mathrm{Ni}$ evolution line of the Fe-Mn crust affected by Mn cycling (Fig. 5B,

419 Gueguen et al., 2016).

420

421 Overall, a consistent picture of the impact of Mn cycling on Ni isotope compositions 422 emerges from the MANOP sediments, Fe-Mn crusts and Mn nodules. Hydrogenetic $423 \delta^{60} \mathrm{Ni}$ values (represented by $\mathrm{Fe}-\mathrm{Mn}$ crusts) are similar to the seawater $\mathrm{Ni}$ isotope 424 composition, with Mn cycling during diagenesis leading to partial dissolution and 425 reprecipitation of phyllomanganates that re-scavenge isotopically light $\mathrm{Ni}$ in a variably 426 open system, associated with decreasing $\mathrm{Mn} / \mathrm{Ni}$ ratios.

\section{Todorokite transformation}

429 During diagenesis, birnessite can also transform (via a $10 \AA$ phase) to the 430 tectomanganate todorokite (Atkins et al., 2014; Wegorzewski et al., 2020). Recent 431 experimental work suggests that this transformation leads to significant Ni release to 432 porewaters, because $\mathrm{Ni}$ is not significantly incorporated in the todorokite crystal 433 structure (Atkins et al., 2016). Consistent with this finding, buried Mn nodules of 434 todorokite exhibit higher $\mathrm{Mn} / \mathrm{Ni}$ ratios compared to phyllomanganate-rich surface 435 nodules (Fig. 5B; Heller et al., 2018; Wegorzewski et al., 2020), i.e. the opposite 436 evolution to that inferred for Mn cycling. Furthermore, buried nodules are isotopically 437 even lighter (at -0.22 to $+0.01 \%$ ) than surface nodules (at +0.28 to $+1.06 \%$ ), 438 suggesting that todorokite transformation may lead to further Ni isotope fractionation. 
440 However, the relevance of todorokite transformation to the $\mathrm{Ni}$ isotope composition of 441 the MANOP sediments, and to marine Ni cycling more broadly, remains unclear, 442 because the timescale and mechanism of todorokite transformation and its prevalence 443 in marine sediments is difficult to establish. Typically considered a process of 444 phyllomanganate ageing under oxic conditions, oxic transformation of birnessite to 445 todorokite in the lab has only been achieved at higher than ambient temperatures 446 and/or lower than circumneutral pH (e.g., Atkins et al., 2014). Recently, Jung et al. 447 (2020) demonstrate that cyclic redox fluctuations (driven in the lab by cyclic 448 voltammetry) can also trigger the layer-to-tunnel phase transformation. Cyclic redox 449 fluctuations are common in marine sediments, suggesting that todorokite 450 transformation may occur outside of fully oxic diagenetic settings. Nevertheless, 451 identification of todorokite by XRD is currently impossible at the low abundances 452 present in marine sediments, due to the similar crystallographic structure of different 453 Mn oxide polymorphs. While our XRD data for the MANOP sediments indicates the 454 presence of a phyllomanganate phase, we cannot rule out the occurrence of more 455 crystalline todorokite at low abundance. Geochemically, MANOP $\mathrm{Mn} / \mathrm{Ni}$ ratios are 456 more similar to those of the buried, todorokite-rich Mn nodules than to surface 457 nodules, but they are also similar to hydrogenetic Pacific Fe-Mn crusts (Fig. 5B).

459 Future experimental work will test the hypothesis that todorokite transformation leads 460 to preferential retention of isotopically light $\mathrm{Ni}$ in the solid phase, and investigate the 461 relationships between the transformation mechanism, Ni release, and evolving $\mathrm{Mn} / \mathrm{Ni}$ 462 ratios. 

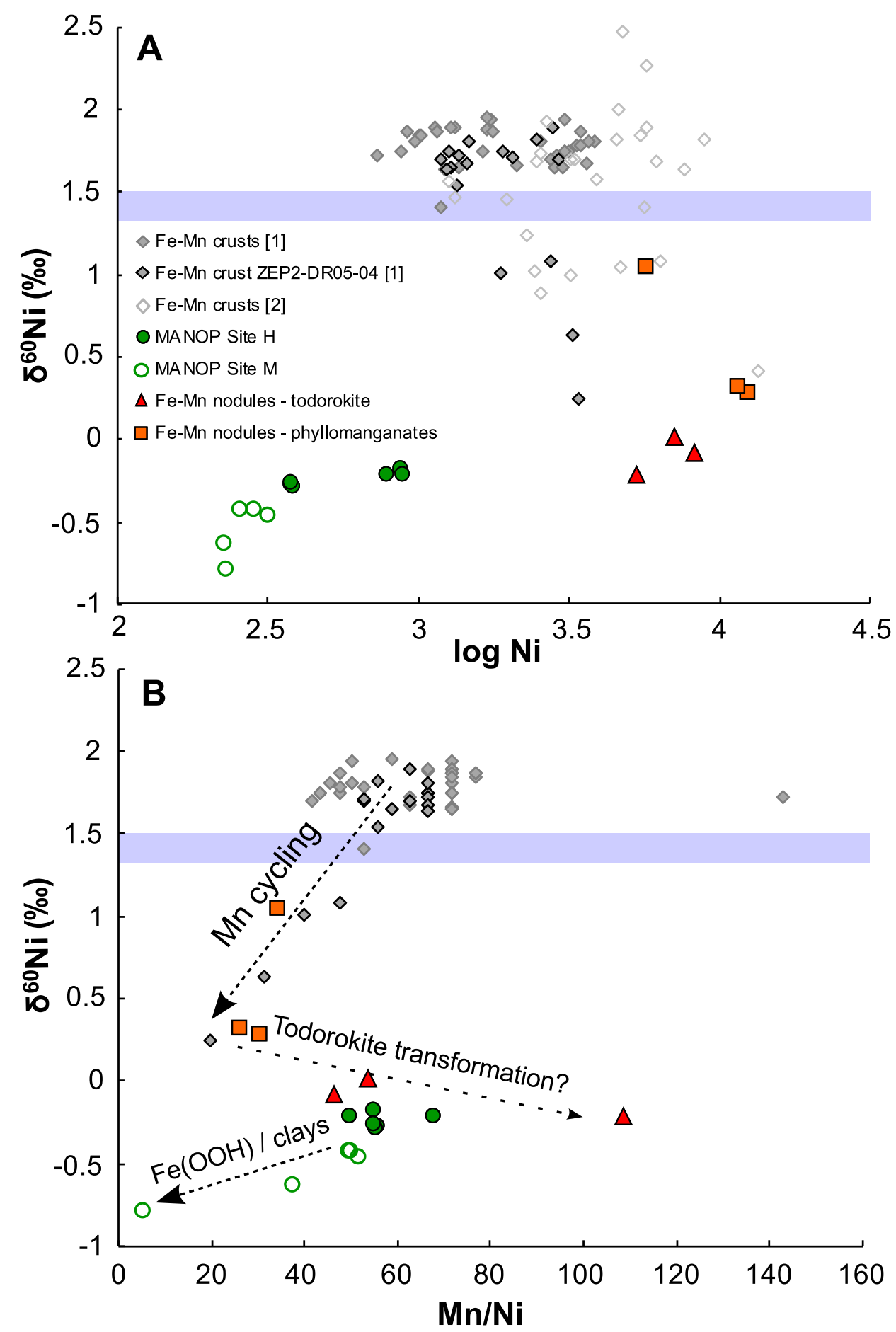

465 Figure 5. A) $\log \mathrm{Ni}$ concentration and B) $\mathrm{Mn} / \mathrm{Ni}$ ratios versus $\delta^{60} \mathrm{Ni}$ values for samples 466 from MANOP site H (green filled circles), MANOP site M (green open circles), Mn 467 nodules of predominantly phyllomanganates (orange squares) and todorokite (red 468 triangles), and literature values for Fe-Mn crusts (grey diamonds). Labelled dashed 469 arrows in B represent the proposed diagenetic effects of Mn cycling, todorokite 470 transformation, and scavenging by $\mathrm{Fe}$ (hydr)oxides or authigenic clays (see text for 471 details). Error bars on $\delta^{60} \mathrm{Ni}$ values are approximately the size of the symbols $( \pm$ 472 0.07\%). Literature data: [1] Gueguen et al. (2016) and [2] Gall et al. (2013) (Note: No 473 Mn data are presented by Gall et al., 2013). 
5.3 Nickel isotope fractionation during diagenesis: Fe (hydr)oxides or authigenic

475

476

477 clays?

We suggest that the diagenetic cycling of $\mathrm{Ni}$ coupled to $\mathrm{Mn}$ is the key control on the $\mathrm{Ni}$ isotope compositions of the MANOP sediments. However, the sample with the lightest $\mathrm{Ni}$ isotope composition (at $-0.79 \%$ ), from $18 \mathrm{~cm}$ depth at site $\mathrm{M}$, has the lowest $\mathrm{Mn}$ concentration $(0.12 \mathrm{wt} \%)$ and lowest $\mathrm{Mn} / \mathrm{Ni}$ ratio (5.4, Fig. 5B). Despite limited Mn enrichment, this sample is significantly $\mathrm{Ni}$ enriched $(\mathrm{Ni} / \mathrm{Al}=0.0056 \mathrm{cf}$. $\left.\mathrm{Ni} / \mathrm{Al}_{\mathrm{UCC}}=0.0006\right)$. Together, these observations suggest an additional control on $\mathrm{Ni}$ isotope compositions in low Mn sediments. We consider two possibilities: (1) sorption of isotopically light $\mathrm{Ni}$ on nanoscale $\mathrm{Fe}$ (hydr)oxides, and (2) incorporation of isotopically light $\mathrm{Ni}$ in Fe-rich authigenic clays.

\section{Nanoscale Fe oxides}

Iron is significantly more enriched at site $\mathrm{M}(\mathrm{Fe} / \mathrm{Al} \sim 1.3)$ compared to site $\mathrm{H}(\mathrm{Fe} / \mathrm{Al}$ $\sim 0.8$; Fig. 3), with the difference attributed to the presence of hydrothermal precipitates at site M (Fischer, 1983). Sorption of Ni on Fe (hydr)oxides is less energetically favoured than on phyllomanganates, due to the higher $\mathrm{pH}_{\mathrm{pzc}}$ for $\mathrm{Fe}$ (hydr)oxide phases (at about 7 to 8 ) compared to $\mathrm{MnO}_{2}$ (at about 2, Stumm and Morgan, 1996; Tripathy and Kanungo, 2005). Nevertheless, when phyllomanganates are scarce, Fe (hydr)oxide phases become environmentally relevant.

Experimental investigations of $\mathrm{Ni}$ isotope fractionation on sorption to ferrihydrite

97 found $\Delta^{60} \mathrm{Ni}_{\text {ferrihydrite-aqueous }}=-0.35 \%$ (Wasylenki et al., 2015; Gueguen et al., 2018).

98 For Ni coprecipitation with ferrihydrite, Wang and Wasylenki (2017) found that the 
499 fractionation factor increased from -0.08 to $-0.50 \%$ with increased co-precipitation 500 (e.g., at higher $\mathrm{pH}$ ). Sorption to goethite is associated with a larger fractionation factor, $501 \Delta \Delta^{60} \mathrm{Ni}_{\text {goethite-aqueous }}=-0.77 \%$ o (Gueguen et al., 2018). A correlation is observed between $502 \mathrm{Fe} / \mathrm{Ni}$ and $\mathrm{Ni}$ isotope compositions at site $\mathrm{M}$ (Fig. 6A), consistent with the hypothesis 503 of scavenging of isotopically light $\mathrm{Ni}$ by Fe (hydr)oxide phases. We envisage that this 504 process occurs during diagenesis, due to the evolution towards lighter $\mathrm{Ni}$ isotope 505 compositions at site M compared to site H. (Fig. 6A) However, it is also feasible that 506 dissolved $\mathrm{Ni}$ is scavenged by hydrothermal $\mathrm{Fe}$ precipitates suspended in the water 507 column and which subsequently settle out.

509 Interestingly, $\delta^{60} \mathrm{Ni}$ also correlates with published $\delta^{98} \mathrm{Mo}$ values for the MANOP 510 samples (Fig 6B; Poulson Brucker et al., 2009). Like Ni, Mo cycling has been strongly 511 linked to $\mathrm{Mn}$ in oxic marine sediments, but a role for sorption to Fe (hydr)oxides in the 512 oceanic Mo cycle has also been proposed (Goldberg et al., 2009). Molybdenum 513 sorption on Mn oxides exhibits a stronger preference for light isotopes (e.g., Barling 514 and Anbar, 2004) than Mo sorption on Fe (hydr)oxides (Goldberg et al., 2009). Thus, 515 these two competing controls on Mo isotope compositions appear to be consistent with 516 the MANOP $\delta^{98}$ Mo values, in which the site M samples (rich in $\mathrm{Fe}$ ) are isotopically 517 heavier than those of site $\mathrm{H}$ (rich in $\mathrm{Mn}$ ). 


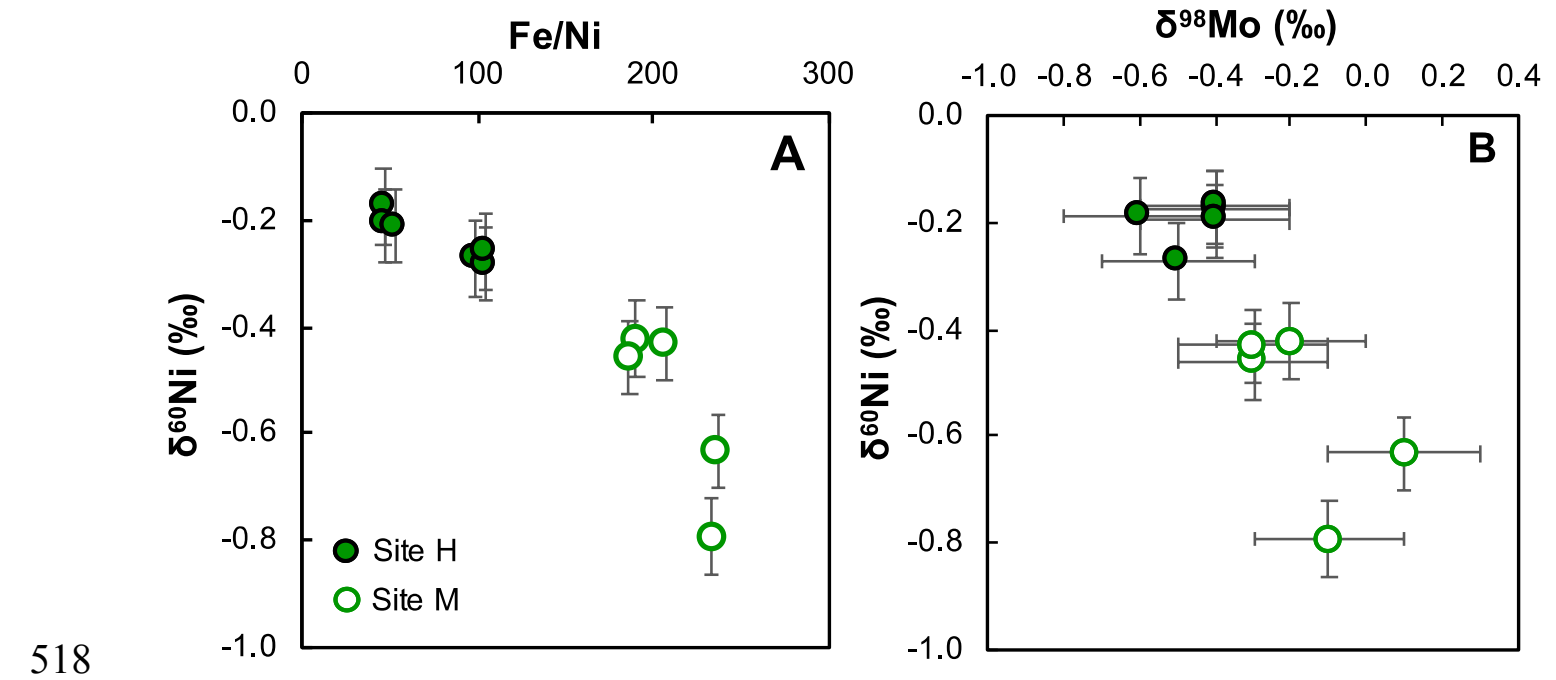

300

$\delta^{98} \mathrm{Mo}(\%)$

519 Figure 6. Relationships between A. Fe/Ni and B. $\delta^{98}$ Mo (data: Poulson Brucker et al., 5202009 ) and $\mathrm{Ni}$ isotope compositions at the two MANOP sites. Error bars on $\delta^{60} \mathrm{Ni}$ are 521 the long-term reproducibility $\left( \pm 0.07 \%\right.$ ) and on $\delta^{98}$ Mo are $\pm 0.20 \%$ o (the estimated 522 external reproducibility on bulk $\delta^{98}$ Mo values from Poulson Brucker et al., 2009).

\section{Authigenic clay minerals}

525 Though it has long been inferred that authigenic Fe (hydr)oxide coatings are an 526 important host phase for trace elements in marine sediments, direct image-based 527 identification of these phases has proven challenging. The XRD technique utilised in 528 this study, for example, has a detection limit of $\sim 2 \mathrm{wt} \%$ for Fe (hydr)oxide phases. 529 However, it has been suggested that part of the challenge in directly observing $\mathrm{Fe}$ 530 (hydr)oxide coatings reflects the fact that authigenic Fe is (at least partly) hosted in 531 authigenic clay minerals (e.g., Abbott et al., 2019). By extension, it is possible that Fe 532 (hydr)oxides are not as quantitatively important scavengers of trace elements, and that 533 authigenic clay minerals play an under-appreciated role (e.g., Hein et al., 1979; Abbott 534 et al., 2019).

536 The dominant mineral phase at both MANOP sites is smectite; indeed, authigenic 537 smectite (Fe-rich montmorillonite) makes up 26 to $66 \%$ of the clays present in north 538 equatorial Pacific sediments (Hein et al., 1979). Hein et al. (1979) found that this 
539 smectite contains $70-150 \mu \mathrm{g} / \mathrm{g} \mathrm{Ni}$, though the clay fraction analysed may have 540 included sorbed nanoscale Fe (hydr)oxides. Nevertheless, using x-ray absorption 541 spectroscopy, Merrot et al. (2019) find that $\mathrm{Ni}$ is primarily hosted by Fe-rich smectite 542 and early diagenetic greenalite in lagoon sediments. During terrestrial weathering, Ni 543 liberated from primary minerals is concentrated by smectite, where present (e.g., Ratié 544 et al., 2018). Furthermore, the smectitic zone of a weathering profile is characterized 545 by light $\mathrm{Ni}$ isotope compositions compared to the protolith (Ratié et al., 2018), 546 consistent with experimental results indicating a small light isotope effect on sorption 547 to Na-montmorillonite (a form of smectite), of $-0.11 \pm 0.09 \%$ (Spivak-Birndorf et al., 548 2018). We suggest that better evaluation of the role of authigenic clays in sedimentary 549 trace element budgets should be a target for future research.

\subsection{Implications for whole oceanic mass balance}

554 Assuming steady state, there is a significant flux and isotopic mass imbalance in the 555 oceanic Ni cycle, summarised most recently by Ciscato et al. (2018). In their analysis, 556 the input of $\mathrm{Ni}$ (riverine dissolved $\mathrm{Ni}$ and $\mathrm{Ni}$ from mineral dust) is $3.7 \times 10^{8} \mathrm{~mol} /$ year, 557 with $\delta^{60} \mathrm{Ni}_{\text {input }}=+0.79 \%$. By contrast, the estimated output flux to sediments ranges 558 from 7.2 to $17 \times 10^{8} \mathrm{~mol} /$ year (i.e. $2-5$ times larger than the estimated input flux), with $559 \delta^{60} \mathrm{Ni}_{\text {output }} \approx+1.5 \%$. By far the dominant feature of the existing $\mathrm{Ni}$ budget is the 560 removal flux to dispersed Fe-Mn oxides in 'oxic sediments' (where oxygen penetrates 561 to $>1 \mathrm{~cm}$ depth; Morford and Emerson, 1999), which is estimated to range from 5.8 to $56210.5 \times 10^{8} \mathrm{~mol} / \mathrm{yr}$ (Gall et al., 2013; Cameron and Vance, 2014). The isotopic 
composition of this oxic sink has been assumed to reflect that of Fe-Mn crusts, at

564 about $+1.6 \%$.

566 Ciscato et al. (2018) suggest that the previously assumed flux of Ni to the oxic sink, 567 and its isotopic composition, might be erroneous. Balancing the budget would require 568 an oxic sink of $1.8 \times 10^{8} \mathrm{~mol} / \mathrm{yr}$ (3-5 times smaller than previously estimated), with an 569 average isotopic composition of about $+0.5 \%$. Our study suggests a resolution of this 570 problem, via the diagenetic remobilization of isotopically heavy $\mathrm{Ni}$ and its release into 571 bottom waters. From here on, we assume that this diagenetic remobilization and 572 release occurs in sub-oxic (specifically, Mn reducing) settings. However, we note that 573 todorokite transformation may also occur in oxic settings, and thus this process may be 574 significantly underrepresented in the following assessment.

576 First, we recalculate the Ni burial flux in oxic sediments by coupling to estimates for $577 \mathrm{Mn}$. The authigenic accumulation rate of $\mathrm{Mn}$ in pelagic clays is estimated at $6-23$ $578 \mu \mathrm{mol} / \mathrm{cm}^{2} / \mathrm{kyr}$ (best guess: $13 \mu \mathrm{mol} / \mathrm{cm}^{2} / \mathrm{kyr}$ ) (Rehkämper and Nielsen, 2004 and 579 references therein). The $\mathrm{Ni} / \mathrm{Mn}$ ratio of the MANOP site $\mathrm{H}$ sediments and of $\mathrm{Fe}-\mathrm{Mn}$ 580 crusts is 0.019 (by weight; USGS compilation of Manheim and Lane-Bostwick, 1991). 581 Of the sediment types described in the marine sediment census of Dutkiewicz et al. 582 (2015), we include only 'clay' $(40.2 \%$ ocean area) in this category. The remainder are 583 predominantly calcareous oozes, which have a low Mn content (Morford and 584 Emerson, 1999 and references therein), though we note that two 'transitional' 585 sediment types ('siliceous mud', 5.0\% and 'fine-grained calcareous sediment', 12.4\%; 586 Dutkiewicz et al., 2015) may be a significant Mn sink and should be a target of future 587 studies. We estimate a Ni burial flux to oxic sediments (in this case, exclusively clay) 
of 1.5 to $5.9 \times 10^{8} \mathrm{~mol} / \mathrm{yr}$ (Table 3 ). Nickel burial in association with carbonates is

589 negligible on this scale, at about $0.14 \times 10^{8} \mathrm{~mol} /$ year (Ciscato et al., 2018). Following

590 previous authors, we assume that the $\mathrm{Ni}$ isotope composition of oxic sediments is

591 represented by Fe-Mn crusts, at $+1.62 \pm 0.37 \%$ (1 SD, Table 3; Gall et al., 2013;

592 Gueguen et al., 2016).

593

594 Next, we estimate the benthic return flux of Ni from sub-oxic sediments, also by 595 comparison to Mn. Morford and Emerson (1999) estimate that sub-oxic sediments 596 (defined as those deposited at $>1000 \mathrm{~m}$ water depth for which oxygen penetrates to $\leq 1$ $597 \mathrm{~cm}$ ) cover $\sim 4 \%$ of the ocean area. They estimate a sub-oxic benthic Mn flux of $0.7-$ $5981.3 \times 10^{10} \mathrm{~mol} / \mathrm{yr}$ (Morford and Emerson, 1999). Our study suggests that Mn 599 diagenesis leads to preferential retention of $\mathrm{Ni}$ in sediments compared to Mn (Fig. 5B), 600 but todorokite transformation should have the opposite effect (Fig. 5B; Atkins et al., 601 2016). Direct measurements of porewater Ni/Mn ratios for the MANOP sediments are 602 variable, but generally similar to the solid phase (i.e. $\sim 0.019)$ ranging from $0.005-$ 6030.031 (mean site $\mathrm{M}=0.009$, mean site $\mathrm{H}=0.020$; Klinkhammer, 1980). For an 604 estimated $\mathrm{Ni} / \mathrm{Mn}$ range of $0.009-0.020$, we calculate a benthic Ni flux of $0.6-2.3 \mathrm{x}$ $60510^{8} \mathrm{~mol} / \mathrm{yr}$.

606

607 Next, we solve for the isotopic composition of the benthic flux by expanding equation

608 (1) for all known fluxes and assuming steady state, where:

609

610

$$
\mathrm{F}_{\text {river }} \delta_{\text {river }}+\mathrm{F}_{\text {dust }} \delta_{\text {dust }}+\mathrm{F}_{\text {benthic }} \delta_{\text {benthic }}=\mathrm{F}_{\text {oxic }} \delta_{\text {oxic }}+\mathrm{F}_{\text {org }} \delta_{\text {org }}+\mathrm{F}_{\text {eux }} \delta_{\text {eux }}+\mathrm{F}_{\text {carb }} \delta_{\text {carb }}
$$


612 In equation (3), the Ni sources include rivers, dust and the benthic flux, while the sinks

613 are pelagic clays ('oxic'), organic-rich sediments on continental margins ('org'),

614 euxinic sediments ('eux') and carbonates ('carb').

615

616 We carry out a Monte Carlo simulation (10,000 iterations), allowing each flux to vary

617 within its given range (flux and $\delta^{60} \mathrm{Ni}$; values given in italics in Table 3 ) and solving

618 for the benthic flux required to balance the Ni mass budget (model results in bold in

619 Table 3). Flux magnitudes were forced by uniformly distributed random numbers, and

620 isotopic compositions by normally distributed random numbers (around the mean and

621 standard deviation of published data, see Table 3). For further discussion of the

622 approach, see the Supplementary Information. Note that the carbonate and euxinic

623 sinks, and the dust source, are minor, and therefore represented in the simulation

624 simply by the best guess at their magnitudes and isotopic compositions (Table 3 ). The

625 riverine flux is included as the concentration and discharge-weighted average of

626 Cameron and Vance (2014). Post-simulation, the benthic flux range was restricted to

$6270.6-2.3 \times 10^{8} \mathrm{~mol} / \mathrm{yr}$, with the side effect of reducing the maximum output flux to

628 pelagic clays to $4.6 \times 10^{8} \mathrm{~mol} / \mathrm{yr}$ (see SI for further discussion).

630 This analysis suggests that the isotopic composition of the benthic flux required to

631 balance the oceanic Ni budget is approximately $+3 \%$ (Table 3 ). Compared to the

632 isotopic composition of oxic sediments (at $+1.6 \%$ ), this equates to an effective

633 fractionation factor for diagenesis of about $-1.4 \%$ (averaged globally). This value is

634 comparable to the observed isotopic difference between the MANOP sediments (at

635 about -0.2 to $-0.8 \%$ ) and the possible sources of $\mathrm{Ni}$ to the site (at about +0.1 to 
$636+1.6 \%$; Section 5.1), supporting the hypothesis that diagenetic remobilisation of 637 isotopically heavy Ni can balance the oceanic Ni budget.

638

639 
Table 3. Modelled oceanic mass balance of $\mathrm{Ni}$ and $\mathrm{Ni}$ isotopes (see text and $\mathrm{SI}$ for full 641 details). Values in italics were used in the Monte Carlo simulation. Values in bold are 642 outputs from the model.

\begin{tabular}{|c|c|c|c|c|}
\hline & \multicolumn{2}{|c|}{ Flux $\left(\times 10^{8} \mathrm{~mol} / \mathrm{yr}\right)$} & \multicolumn{2}{|c|}{$\delta^{60} \mathrm{Ni}(\%)$} \\
\hline & Range & Best guess & $\begin{array}{c}\text { Mean and SD } \\
\text { or range }\end{array}$ & Best guess \\
\hline \multicolumn{5}{|l|}{ Source fluxes } \\
\hline Rivers $^{\mathrm{a}}$ & - & 3.60 & - & 0.8 \\
\hline $\operatorname{Dust}^{\mathrm{b}, \mathrm{c}}$ & - & 0.076 & -0.09 to 0.37 & 0.14 \\
\hline Benthic & 0.6 to 2.3 & 1.44 & $3.17 \pm 1.08$ & $3.03^{*}$ \\
\hline \multicolumn{5}{|l|}{ Sink fluxes } \\
\hline Pelagic clays & 1.5 to $4.6(5.9)$ & 3.08 & $1.62 \pm 0.37^{\mathrm{d}}$ & 1.62 \\
\hline Organic-rich $^{b}$ & 1.1 to 2.4 & 1.74 & $1.12 \pm 0.08$ & 1.12 \\
\hline Carbonates $^{\mathrm{b}}$ & 0.031 to 0.44 & 0.14 & 1.10 to 1.64 & 1.29 \\
\hline Euxinic $^{\mathrm{b}}$ & 0.093 to 0.25 & 0.15 & 0.3 to $0.6^{\mathrm{c}}$ & 0.45 \\
\hline Total in/out & 4.3 to 6.0 & 5.1 & $1.41 \pm 0.23$ & 1.40 \\
\hline Residence time $^{1}$ & 18 to $25 \mathrm{kyr}$ & $21 \mathrm{kyr}$ & & \\
\hline
\end{tabular}

643

644

645

646

647

648

649

650

651

652

653

654

655

656

657

658

659

660

\section{Conclusions}

${ }^{*}$ Best guess $\delta^{60} \mathrm{Ni}$ is the median value output by the model (For details see SI, Fig. S8).

${ }^{1}$ Residence time calculated given a global ocean volume of $1.35 \times 10^{21} \mathrm{~kg}$ and mean $\mathrm{Ni}$ concentration of $8 \mathrm{nM}$ (i.e. $1.08 \times 10^{13}$ moles Ni).

References: ${ }^{\mathrm{a} C a m e r o n}$ and Vance (2014), ${ }^{\mathrm{b}}$ Ciscato et al. (2018), ${ }^{\mathrm{c}}$ Vance et al. (2016), ${ }^{\mathrm{d}}$ Gall et al. (2013).

We report Ni isotope compositions for metalliferous sediments from two of the eastern Pacific MANOP sites. Both sites exhibit very light Ni isotope compositions (at -0.8 to $-0.2 \%$ ) compared to hydrogenetic Fe-Mn crusts (at $+1.6 \%$ ). Low but variable $\delta^{60} \mathrm{Ni}$ values are also observed for Mn nodules $(-0.2$ to $+1.0 \%$ ). We propose two primary mechanisms to explain the isotopically light diagenetic $\mathrm{Ni}$ 'fingerprint': (1) $\mathrm{Mn}$ cycling, in which $\mathrm{Ni}$ cycling is coupled to the redox-driven dissolution and reprecipitation of $\mathrm{Mn}$ oxides, and (2) the mineralogical transformation of birnessite to todorokite, which may occur in oxic or sub-oxic sedimentary environments. In Mnpoor oxic sediments we suggest that additional $\mathrm{Ni}$ (and $\mathrm{Mo}$ ) isotope fractionation 
661 accompanies the scavenging of isotopically light Ni by nanoscale Fe (hydr)oxides or 662 Fe-rich authigenic clays.

663

664 We hypothesize that diagenetic remobilization of isotopically heavy Ni balances the 665 oceanic Ni budget. Based on estimates for Mn, we calculate a benthic Ni flux of 0.6 to $6662.3 \times 10^{8} \mathrm{~mol} / \mathrm{yr}$, comparable in magnitude to the riverine Ni flux, at $3.6 \times 10^{8} \mathrm{~mol} / \mathrm{yr}$.

667 The required isotopic composition of this benthic flux to balance the oceanic $\mathrm{Ni}$ 668 budget is approximately $+3 \%$, providing a testable hypothesis for future studies. Our 669 calculation does not directly consider the under-constrained possibility of Ni release 670 during the transformation of phyllomanganates to todorokite in oxic marine sediments, 671 a process that would not be associated with a benthic Mn flux. Further lab and field672 based investigations are underway targeting the analysis of oxic and sub-oxic

673 sediments and porewaters, and to investigate the $\mathrm{Ni}$ isotope fractionation associated 674 with todorokite transformation.

\section{Acknowledgements}

677 We would like to thank Francis Albarède and an anonymous reviewer for their

678 comments on a previous version of this paper. SHL is supported by a NERC

679 independent research fellowship (NE/P018181/1). ETH involvement in this research

680 was supported by the Swiss National Science Foundation (SNF) through grants

681 200020-16590 and 200021_184873/1 (to DV). JM's contributions were supported by

682 NSF grant 1657832. The authors would like to thank Emily Ciscato and Aditi

683 Chatterjee for helpful discussions during the project, Rhian O'Callaghan for making 684 Figure 1, Caroline Peacock for feedback on an earlier version of the manuscript, and 685 Matthias Haeckel for providing the Peru Basin nodule sample (77BC11-6). 


\section{References}

689

690

691

692

693

694

695

696

697

698

699

700

701

702

703

704

705

706

707

708

709

710

711

712

713

714

715

716

717

Abbott, A.N., Löhr, S., Trethewy, M., 2019. Are Clay Minerals the Primary Control on the Oceanic Rare Earth Element Budget? Front. Mar. Sci. 6, 1-19. https://doi.org/10.3389/fmars.2019.00504

Archer, C., Vance, D., Lohan, M.C., Milne, A., 2020. The oceanic biogeochemistry of nickel and its isotopes: new data from the South Atlantic and the Southern Ocean biogeochemical divide. Earth Planet. Sci. Lett.

Atkins, A.L., Shaw, S., Peacock, C.L., 2016. Release of Ni from birnessite during transformation of birnessite to todorokite: Implications for Ni cycling in marine sediments. Geochim. Cosmochim. Acta 189, 158-183. https://doi.org/10.1016/j.gca.2016.06.007

Atkins, A.L., Shaw, S., Peacock, C.L., 2014. Nucleation and growth of todorokite from birnessite: Implications for trace-metal cycling in marine sediments. Geochim. Cosmochim. Acta 144, 109-125. https://doi.org/10.1016/j.gca.2014.08.014

Barling, J., Anbar, A.D., 2004. Molybdenum isotope fractionation during adsorption by manganese oxides. Earth Planet. Sci. Lett. 217, 315-329. https://doi.org/10.1016/S0012-821X(03)00608-3

Bourne, H.L., Bishop, J.K.B., Lam, P.J., Ohnemus, D.C., 2018. Global Spatial and Temporal Variation of Cd:P in Euphotic Zone Particulates. Global Biogeochem. Cycles. https://doi.org/10.1029/2017GB005842

Bruland, K.W., 1980. Oceanographic distributions of cadmium, zinc, nickel and copper in the North Pacific. Earth Planet. Sci. Lett. 47, 176-198.

Burns, R.G., Burns, V.M., 1979. Manganese oxides, in: Burns, R.G. (Ed.), Marine Minerals. pp. 1-46.

Cameron, V., Vance, D., 2014. Heavy nickel isotope compositions in rivers and the oceans. Geochim. Cosmochim. Acta 128, 195-211. https://doi.org/10.1016/j.gca.2013.12.007

Cameron, V., Vance, D., Archer, C., House, C.H., 2009. A biomarker based on the stable isotopes of nickel. Proc. Natl. Acad. Sci. 106, 10944-10948. https://doi.org/10.1073/pnas.0900726106 
Ciscato, E.R., Bontognali, T.R.R., Vance, D., 2018. Nickel and its isotopes in organicrich sediments: implications for oceanic budgets and a potential record of ancient seawater. Earth Planet. Sci. Lett. 494, 239-250. https://doi.org/10.1016/j.epsl.2018.04.061

Collier, R., Edmond, J., 1984. The trace element geochemistry of marine biogenic particulate matter. Prog. Oceanogr. 13, 113-199. https://doi.org/10.1016/00796611(84)90008-9

Dutkiewicz, A., Müller, R.D., O’Callaghan, S., Jónasson, H., 2015. Census of seafloor sediments in the world's ocean. Geology 43, 795-798. https://doi.org/10.1130/G36883.1

Fischer, K., 1983. Particle Fluxes in the Eastern Tropical Pacific Ocean - Sources and Processes. Oregon State University.

Gall, L., Williams, H.M., Siebert, C., Halliday, A.N., Herrington, R.J., Hein, J.R., 2013. Nickel isotopic compositions of ferromanganese crusts and the constancy of deep ocean inputs and continental weathering effects over the Cenozoic. Earth Planet. Sci. Lett. 375, 148-155. https://doi.org/10.1016/j.eps1.2013.05.019

Goldberg, T., Archer, C., Vance, D., Poulton, S.W., 2009. Mo isotope fractionation during adsorption to Fe (oxyhydr)oxides. Geochim. Cosmochim. Acta 73, 65026516. https://doi.org/10.1016/j.gca.2009.08.004

Gueguen, B., Rouxel, O., Rouget, M.L., Bollinger, C., Ponzevera, E., Germain, Y., Fouquet, Y., 2016. Comparative geochemistry of four ferromanganese crusts from the Pacific Ocean and significance for the use of Ni isotopes as paleoceanographic tracers. Geochim. Cosmochim. Acta 189, 214-235. https://doi.org/10.1016/j.gca.2016.06.005

Gueguen, B., Sorensen, J. V., Lalonde, S. V., Peña, J., Toner, B.M., Rouxel, O., 2018. Variable $\mathrm{Ni}$ isotope fractionation between Fe-oxyhydroxides and implications for the use of Ni isotopes as geochemical tracers. Chem. Geol. https://doi.org/10.1016/j.chemgeo.2018.01.023

Heggie, D., Kahn, D., Fischer, K., 1986. Trace metals in metalliferous sediments, MANOP Site M: interfacial pore water profiles. Earth Planet. Sci. Lett. 80, 106116. https://doi.org/10.1016/0012-821X(86)90023-3

Hein, J.R., Yeh, H.-W., Alexander, E., 1979. Origin of Iron-Rich Montmorillonite from the Manganese Nodule Belt of the North Equatorial Pacific. Clays Clay Miner. 27, 185-194. https://doi.org/10.1346/ccmn.1979.0270303 
Heller, C., Kuhn, T., Versteegh, G.J.M., Wegorzewski, A. V., Kasten, S., 2018. The geochemical behavior of metals during early diagenetic alteration of buried manganese nodules. Deep. Res. Part I Oceanogr. Res. Pap. 142, 16-33. https://doi.org/10.1016/j.dsr.2018.09.008

Hens, T., Brugger, J., Etschmann, B., Paterson, D., Brand, H.E.A., Whitworth, A., Frierdich, A.J., 2019. Nickel exchange between aqueous Ni(II) and deep-sea ferromanganese nodules and crusts. Chem. Geol. 528, 119276. https://doi.org/10.1016/J.CHEMGEO.2019.119276

Jaun, B., Thauer, R.K., 2007. Methyl-Coenzyme M Reductase and its Nickel Corphin Coenzyme F430in Methanogenic Archaea, in: Nickel and Its Surprising Impact in Nature. https://doi.org/10.1002/9780470028131.ch8

Jung, H., Taillefert, M., Sun, J., Wang, Q., Borkiewicz, O.J., Liu, P., Yang, L., Chen, S., Chen, H., Tang, Y., 2020. Redox Cycling Driven Transformation of Layered Manganese Oxides to Tunnel Structures. J. Am. Chem. Soc. https://doi.org/10.1021/jacs.9b12266

Kadko, D.C., 1981. A detailed study of uranium-series nuctides for several sediment reaimes of the Pacific. Columbia University.

Kessler, W.S., 2006. The circulation of the eastern tropical Pacific: A review. Prog. Oceanogr. https://doi.org/10.1016/j.pocean.2006.03.009

Klinkhammer, G.P., 1980. Early diagenesis in sediments from the eastern equatorial Pacific, II. Pore water metal results. Earth Planet. Sci. Lett. 49, 81-101. https://doi.org/10.1016/0012-821X(80)90151-X

Koschinsky, A., Halbach, P., 1995. Sequential leaching of marine ferromanganese precipitates: Genetic implications. Geochim. Cosmochim. Acta 59, 5113-5132. https://doi.org/10.1016/0016-7037(95)00358-4

Koschinsky, A., Hein, J.R., 2003. Uptake of elements from seawater by ferromanganese crusts: Solid-phase associations and seawater speciation. Mar. Geol. 198, 331-351. https://doi.org/10.1016/S0025-3227(03)00122-1

Krishnaswami, S., 1976. Authigenic transition elements in Pacific pelagic clays. Geochim. Cosmochim. Acta 40, 425-434. https://doi.org/10.1016/00167037(76)90007-7

Little, S.H., Sherman, D.M., Vance, D., Hein, J.R., 2014. Molecular controls on Cu and $\mathrm{Zn}$ isotopic fractionation in Fe-Mn crusts. Earth Planet. Sci. Lett. 396, 213 222. https://doi.org/10.1016/j.eps1.2014.04.021 
Lyle, M., Heath, G.R., Robbins, J.M., 1984. Transport and release of transition elements during early diagenesis: Sequential leaching of sediments from MANOP Sites M and H. Part I. pH 5 acetic acid leach. Geochim. Cosmochim. Acta 48, 1705-1715. https://doi.org/10.1016/0016-7037(84)90026-7

Manheim, F.T., Lane-Bostwick, C., 1991. Chemical composition of ferromanganese crusts in the world ocean: a review and comprehensive chemical composition of ferromanganese crusts in the world ocean: a review and comprehensive database. Woods Hole, MA.

Merrot, P., Juillot, F., Noël, V., Lefebvre, P., Brest, J., Menguy, N., Guigner, J.M., Blondeau, M., Viollier, E., Fernandez, J.M., Moreton, B., Bargar, J.R., Morin, G., 2019. Nickel and iron partitioning between clay minerals, Fe-oxides and Fesulfides in lagoon sediments from New Caledonia. Sci. Total Environ. 689, 1212-1227. https://doi.org/10.1016/j.scitotenv.2019.06.274

Morford, J.L., Emerson, S., 1999. The geochemistry of redox sensitive trace metals in sediments. Geochim. Cosmochim. Acta 63, 1735-1750. https://doi.org/10.1016/S0016-7037(99)00126-X

Ohnemus, D.C., Rauschenberg, S., Cutter, G.A., Fitzsimmons, J.N., Sherrell, R.M., Twining, B.S., 2017. Elevated trace metal content of prokaryotic communities associated with marine oxygen deficient zones. Limnol. Oceanogr. 62, 3-25. https://doi.org/10.1002/1no.10363

Palenik, B., Brahamsha, B., Larimer, F.W., Land, M., Hauser, L., Chain, P., Lamerdin, J., Regala, W., Allen, E.E., McCarren, J., Paulsen, I., Dufresne, A., Partensky, F., Webb, E.A., Waterbury, J., 2003. The genome of a motile marine Synechococcus. Nature. https://doi.org/10.1038/nature01943

Peacock, C.L., Sherman, D.M., 2007a. Crystal-chemistry of Ni in marine ferromanganese crusts nodules. Am. Mineral. 92, 1087-1092. https://doi.org/10.2138/am.2007.2378

Peacock, C.L., Sherman, D.M., 2007b. Sorption of Ni by birnessite: Equilibrium controls on Ni in seawater. Chem. Geol. 238, 94-106. https://doi.org/10.1016/j.chemgeo.2006.10.019

Poulson Brucker, R.L., McManus, J., Severmann, S., Berelson, W.M., 2009. Molybdenum behavior during early diagenesis: Insights from Mo isotopes. Geochemistry, Geophys. Geosystems 10. https://doi.org/10.1029/2008GC002180 Price, N.M., Morel, F.M.M., 1991. Colimitation of phytoplankton growth by nickel 

and nitrogen. Limnol. Oceanogr. https://doi.org/10.4319/1o.1991.36.6.1071 Ragsdale, S.W., 2009. Nickel-based enzyme systems. J. Biol. Chem. 284, 1857118575. https://doi.org/10.1074/jbc.R900020200

Ratié, G., Garnier, J., Calmels, D., Vantelon, D., Guimarães, E., Monvoisin, G., Nouet, J., Ponzevera, E., Quantin, C., 2018. Nickel distribution and isotopic fractionation in a Brazilian lateritic regolith: Coupling Ni isotopes and $\mathrm{Ni} \mathrm{K}$-edge XANES. Geochim. Cosmochim. Acta 230, 137-154. https://doi.org/10.1016/j.gca.2018.03.026

Rehkämper, M., Nielsen, S.G., 2004. The mass balance of dissolved thallium in the oceans. Mar. Chem. 85, 125-139. https://doi.org/10.1016/j.marchem.2003.09.006 Rudnick, R.L., Gao, S., 2003. 3.01 - Composition of the Continental Crust. Treatise on Geochemistry 1, 1-64. https://doi.org/http://dx.doi.org/10.1016/B0-08-0437516/03016-4

Sorensen, J. V., Gueguen, B., Stewart, B.D., Peña, J., Rouxel, O., Toner, B.M., 2020. Large nickel isotope fractionation caused by surface complexation reactions with hexagonal birnessite. Chem. Geol. 119481. https://doi.org/10.1016/J.CHEMGEO.2020.119481

Spivak-Birndorf, L.J., Wang, S.J., Bish, D.L., Wasylenki, L.E., 2018. Nickel isotope fractionation during continental weathering. Chem. Geol. https://doi.org/10.1016/j.chemgeo.2017.11.028

Stumm, W., Morgan, J.J., 1996. Metal Ions in Aqueous Solutions: Aspects of Coordination Chemistry, in: Aquatic Chemistry: Chemical Equilibria and Rates in Natural Waters.

Takano, S., Liao, W.H., Tian, H.A., Huang, K.F., Ho, T.Y., Sohrin, Y., 2020. Sources of particulate $\mathrm{Ni}$ and $\mathrm{Cu}$ in the water column of the northern South China Sea: Evidence from elemental and isotope ratios in aerosols and sinking particles. Mar. Chem. 219, 103751. https://doi.org/10.1016/j.marchem.2020.103751

Takano, S., Tanimizu, M., Hirata, T., Shin, K.C., Fukami, Y., Suzuki, K., Sohrin, Y., 2017. A simple and rapid method for isotopic analysis of nickel, copper, and zinc in seawater using chelating extraction and anion exchange. Anal. Chim. Acta 967, 1-11. https://doi.org/10.1016/j.aca.2017.03.010

Tripathy, S.S., Kanungo, S.B., 2005. Adsorption of $\mathrm{Co} 2+$, Ni2+, Cu2+and Zn2+from $0.5 \mathrm{M} \mathrm{NaCl}$ and major ion sea water on a mixture of $\delta-\mathrm{MnO} 2$ and amorphous FeOOH. J. Colloid Interface Sci. 284, 30-38. 
https://doi.org/10.1016/j.jcis.2004.09.054

Twining, B.S., Baines, S.B., Vogt, S., Nelson, D.M., 2012. Role of diatoms in nickel biogeochemistry in the ocean. Global Biogeochem. Cycles 26, 1-9. https://doi.org/10.1029/2011GB004233

Vance, D., Little, S.H., Archer, C., Cameron, V., Andersen, M.B., Rijkenberg, M.J.A., Lyons, T.W., 2016. The oceanic budgets of nickel and zinc isotopes: the importance of sulfidic environments as illustrated by the Black Sea. Philos. Trans. R. Soc. A Math. Phys. Eng. Sci. 374, 20150294. https://doi.org/10.1098/rsta.2015.0294

Wang, R.M., Archer, C., Bowie, A.R., Vance, D., 2018. Zinc and nickel isotopes in seawater from the Indian Sector of the Southern Ocean: The impact of natural iron fertilization versus Southern Ocean hydrography and biogeochemistry. Chem. Geol. 1-13. https://doi.org/10.1016/j.chemgeo.2018.09.010

Wang, S.J., Rudnick, R.L., Gaschnig, R.M., Wang, H., Wasylenki, L.E., 2019. Methanogenesis sustained by sulfide weathering during the Great Oxidation Event. Nat. Geosci. 12. https://doi.org/10.1038/s41561-019-0320-z

Wang, S.J., Wasylenki, L.E., 2017. Experimental constraints on reconstruction of Archean seawater Ni isotopic composition from banded iron formations. Geochim. Cosmochim. Acta 206, 137-150. https://doi.org/10.1016/j.gca.2017.02.023

Wasylenki, L.E., Howe, H.D., Spivak-Birndorf, L.J., Bish, D.L., 2015. Ni isotope fractionation during sorption to ferrihydrite: Implications for Ni in banded iron formations. Chem. Geol. 400, 56-64. https://doi.org/10.1016/j.chemgeo.2015.02.007

Wegorzewski, A. V., Grangeon, S., Webb, S.M., Heller, C., Kuhn, T., 2020. Mineralogical transformations in polymetallic nodules and the change of $\mathrm{Ni}, \mathrm{Cu}$ and Co crystal-chemistry upon burial in sediments. 
Table 2. Mn-rich sediments analysed in this study and their Ni isotope compositions. Other sample details: depth in sediment, XRD (for MANOP) or identified MnOx phase (Mn nodules) selected elemental concentrations (for full list, see Table S2), Ni/Al ratios and Ni enrichment factors (where $\left.\mathrm{EF}=(\mathrm{Ni} / \mathrm{Al})_{\text {sample }} /(\mathrm{Ni} / \mathrm{Al})_{\mathrm{UCC}}\right)$.

\begin{tabular}{|c|c|c|c|c|c|c|c|c|c|c|c|}
\hline & Depth (cm) & XRD analysis? & $\operatorname{Mn}(w t \%)$ & $\mathrm{Fe}(\mathrm{wt} \%)$ & $\mathbf{P}(\mathrm{wt} \%)$ & $\mathrm{Al}(\mathrm{wt} \%)$ & $\mathrm{Ni}(\mu \mathrm{g} / \mathrm{g})$ & $\mathrm{Ni} / \mathrm{Al}$ & Ni EF & $\delta^{60} \mathrm{Ni}$ & $2 \sigma$ \\
\hline \multicolumn{12}{|l|}{ MANOP Site H sediments } \\
\hline VULCAN 37BC MP8950 AAZ & $3-4 \mathrm{~cm}$ & $\checkmark$ & 4.77 & 4.08 & 0.14 & 5.27 & 872 & 0.017 & 54 & -0.17 & 0.04 \\
\hline VULCAN 37BC MP5306 AAZ & $5-7 \mathrm{~cm}$ & & 4.42 & 4.23 & 0.15 & 5.41 & 892 & 0.016 & 54 & -0.18 & 0.05 \\
\hline Repeat & & & & & & & & & & -0.24 & 0.03 \\
\hline VULCAN 37BC MP5307 AAZ & $7-9 \mathrm{~cm}$ & $\checkmark$ & 5.34 & 4.15 & 0.14 & 5.29 & 785 & 0.015 & 49 & -0.21 & 0.04 \\
\hline VULCAN 37BC MP5310 AAZ & $13-15 \mathrm{~cm}$ & & 2.12 & 3.75 & 0.13 & 4.80 & 379 & 0.008 & 26 & -0.27 & 0.05 \\
\hline VULCAN 37BC MP5312 AAZ & $17-19 \mathrm{~cm}$ & & 2.12 & 3.99 & 0.15 & 5.17 & 382 & 0.007 & 24 & -0.29 & 0.06 \\
\hline Repeat & & & & & & & & & & -0.28 & 0.05 \\
\hline VULCAN 37BC MP5313 AAZ & $19-21 \mathrm{~cm}$ & $\checkmark$ & 2.09 & 3.99 & 0.15 & 5.26 & 379 & 0.007 & 24 & -0.26 & 0.03 \\
\hline \multicolumn{12}{|l|}{ MANOP Site M sediments } \\
\hline PLUTO 20BC MP8966 AAZ & $0.5-1 \mathrm{~cm}$ & & 1.43 & 5.45 & 0.12 & 4.16 & 286 & 0.007 & 23 & -0.42 & 0.04 \\
\hline PLUTO 20BC MP8967 AAZ & $1-3 \mathrm{~cm}$ & $\checkmark$ & 1.65 & 5.92 & 0.13 & 4.69 & 317 & 0.007 & 22 & -0.46 & 0.04 \\
\hline PLUTO 20BC MP8969 AAZ & $5-7 \mathrm{~cm}$ & & 1.27 & 5.30 & 0.12 & 4.19 & 256 & 0.006 & 20 & -0.43 & 0.04 \\
\hline PLUTO 20BC MP8971 AAZ & $9-11 \mathrm{~cm}$ & & 0.85 & 5.40 & 0.11 & 4.23 & 228 & 0.005 & 18 & -0.63 & 0.04 \\
\hline PLUTO 20BC MP8975 AAZ & $17-19 \mathrm{~cm}$ & & 0.12 & 5.35 & 0.09 & 4.11 & 229 & 0.006 & 18 & -0.79 & 0.05 \\
\hline Mn Nodules & Depth (cm) & Main MnOx phase & & & & & & & & & \\
\hline USGS NodA1 & Surface & Phyllomanganates & 19.8 & 9.75 & 0.45 & 1.63 & 5732 & 0.352 & 1153 & 1.06 & $0.02^{*}$ \\
\hline USGS NodP1 & Surface & Phyllomanganates & 30.1 & 4.91 & 0.16 & 1.36 & 11559 & 0.850 & 2784 & 0.34 & $0.05^{*}$ \\
\hline $21 \mathrm{KG}-1 \mathrm{n}$ & Surface & Phyllomanganates & 31.6 & 4.29 & 0.11 & 1.57 & 11000 & 0.790 & 2587 & 0.28 & 0.03 \\
\hline 77BC-6 & Shallow buried & Todorokite & 48.2 & 0.62 & 0.05 & 0.67 & 1884 & 0.793 & 2599 & -0.22 & 0.04 \\
\hline $22 \mathrm{KL}-530 \mathrm{~cm}$ & Buried, $530 \mathrm{~cm}$ & Todorokite & 31.7 & 3.23 & 0.09 & 1.83 & 10328 & 0.452 & 1482 & -0.08 & 0.04 \\
\hline $22 \mathrm{KL}-801 \mathrm{~cm}$ & Buried, $801 \mathrm{~cm}$ & Todorokite & 31.9 & 3.37 & 0.09 & 2.03 & 11492 & 0.351 & 1150 & 0.01 & 0.03 \\
\hline
\end{tabular}

